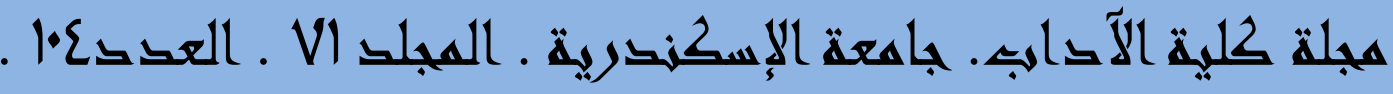

\title{
A Discursive Analysis of Public-directed Institutional Discourse: A Case Study of the Covid-19 Pandemic
}

By: Dr. Nahla Mohamed Nageeb khalil

Lecturer of linguistics

English Department- Faculty of Arts

Damanhour University 


\begin{abstract}
This research deals with the issue of Public-directed Institutional Scientific register. It is one type of register determined by specific situational features and typical linguistic choices. The case study under analysis is Covid-19 pandemic conference held on 29 January 2020 by the World Health Organization (WHO). This research investigates the typical situational features and their influence on the lexico-grammatical choices made by the participants in Public-directed Institutional Scientific register. It reveals how the communication channel and setting influence the register under investigation. In addition, the participants' epistemic and attitudinal stance is analyzed to predict the linguistic features of Public-directed Institutional Scientific register in future conferences. To achieve these aims, the approach of Biber and Conrad (2019) as delineated in their book Register, Genre, and Style is used in the analysis of the data under investigation. Results suggest that situational features of Public-directed Institutional Scientific register include two kinds of institutional addressors, i.e., scientists who provide most of the contributions and journalists who have limited contributions. Findings also reveal that the use of first person plural pronoun, adverbials expressing source of knowledge and doubt, and declarative sentences are prominent lexico-grammatical features of the scientists' contributions in the register under investigation.
\end{abstract}

\title{
Keywords
}

Situational -register - functional -linguistic -epistemic -attitudinal participants - channel- coronavirus- World Health Organization

\section{Introduction}

Currently the epidemic corona virus is the burning question. The public directed institutional scientific register of epidemics is one of the most prominent register types in international health conferences. This research investigates the frequent and pervasive linguistic features typical of institutional scientific register directed to the public by scientists.

\section{Aims of the Study}

This research aims at providing situational and linguistic analysis of the institutional scientific register directed to the public. The situational analysis includes the participants; their personal and social relations; the importance of shared and specific knowledge in register interpretation; 
and the influence of all these factors on the distinctive linguistic structures of the register under investigation.

The influence of the channel and the setting on the production circumstances of the public directed institutional scientific register of epidemics is the second aim of this research. A third aim is to reveal the nature and kind of the communicative purposes $(\mathrm{CPs})$ in the register under investigation and their influence on the semantic sets, i.e., vocabulary.

Speaker's epistemic and attitudinal stance is another situational feature under investigation and the linguistic markers used by the scientists to express their stance. Finally, this study clarifies the influence of all the situational elements on the lexico-grammatical features used by the speakers, accordingly to predict the linguistic and situational features of scientific register directed to the public in future conferences.

\section{Methodology and Data Analysis}

This research uses the sociolinguistic approach of Biber and Conrad (2019) as delineated in their book Register, Genre, and Style. Biber and Conrad specify three levels of register analysis: situational, linguistic, and functional. The approach of Biber and Conrod (2019) is selected for a variety of reasons. To the researcher's knowledge, it has not been applied on the institutional scientific register of WHO. Second, it pays considerable attention to the situational features of institutional scientific register, kinds of participants, such as the institutional addressors. Other situational features relevant to institutional scientific register are the social status of the participants, their communicative purposes, and their attitudinal and epistemic stance. Linguistically, Biber and Conrad's approach focus on the pervasive and frequent lexico-grammatical features of the participants' contributions. Finally, it clarifies the relation between the distinctive situational features and the most frequent and pervasive linguistic features of institutional scientific register throughout the functional level of analysis. The selected approach for analyzing institutional scientific register clarifies the functional use of language in relation to the situational features.

Achieving the aims of this study requires using software to analyze the data under analysis. Antconc 3.5.8 (2019) by Laurence Anthony is the software selected for a number of reasons. First, detection of keyword in context (KWIC) is achieved by the concordance tool. Second, showing the distribution of the frequent and prevalent linguistic features is accomplished by using the concordance plot tool. Third, specifying the 
positions and syntactic categories of the prevalent linguistic features within the data under analysis is achieved by the File View Tool. For example, the lexeme "sharing" is a premodifier in ".....starts from sharing information" and a present continuous verb in "we are showing information". Fourth, specifying the most frequent clusters of linguistic features is achieved by using the Clusters Tools. For example, if the plural pronoun "we" is repeated 59 times, the Cluster Tool can be used to show that "we" is repeated 39 times in cluster "we are"; 38 times in cluster "we have"; and 17 times in cluster "we do". Finally, Antconic software is used to show the frequency of the grammatical categories in the data under analysis by using the Word List Tool.

The data of analysis is the WHO international conference on Covid-19 entitled "Novel Corona Virus Press Conference at United Nations of Geneva" held on 29 January 2020. The selected extracts represent the scientific register delivered by the three scientists in the conference under analysis. The extracts are divided into three samples. Sample (1) includes the contributions of Dr. Mike Rayan; the second sample is provided by Dr. Maria Van Kerkhove; and the third sample is provided by Dr. Tedros Adhanom Ghebreyesus.

The data of analysis are carefully chosen to represent the scientific and the institutional register. The scientific register is represented in the addressors' scientific vocations and specialty. Dr. Mike Rayan is an Irish doctor specialized in public health and communicable disease control. Dr. Kerkhove is an American doctor specialized in emerging infectious diseases. Dr. Ghebreyesus is a biologist and public health researcher. The institutional register appears in the addressor's professional affiliation to WHO. It is an international organization responsible for the leading role in addressing global health issues, proving technical support to countries, setting norms and standards, and monitoring the pandemics that devastate human kind. The addressor's institutional identities appear in the positions they hold in WHO: Dr. Rayon is the executive director for health emergencies in WHO; Dr. Kerkhove is the head of emerging diseases and zoonosis in WHO; and Dr. Ghebreyesus is the directorgeneral of WHO. Finally, the multiple scientific and institutional issues discussed in the press conference under analysis are another intentional reason for choosing 29 January conference of WHO. Among these issues are the direct-general briefing of his visit to China; presentation of an update of WHO response to Covid-19; and a declaration of reconvening of the EC based on the continued increase of Covid-19. The words and phrases under analysis are underlined for clarification. 


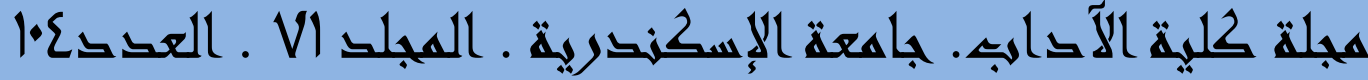

\section{Theatrical Background}

Neumann (2014, p. 1-2) states that variation is an essential feature of any language. It appears in all levels of linguistic use: phonological, lexical, and structural. It is classified into four main kinds: regional variation, social variation, historical variation, and functional variation. Regional variation stems from the linguistic difference as a result of different regions. Social variation is attributed to social stratification of societies. Historical variation results from evolution and interaction with other languages. Finally, functional variation proceeds from the situation in which language is used. Register is one kind of functional variation. It is defined by Neumann from top-down and bottom-up perspective as follows:

Viewed from this top-down perspective, registers are described as subsystems of the language system. In a bottom-up perspective, registers can also be described as groupings of texts sharing similar features that can be explained in turn by the shared context of situation (2).

Holmes (2013, p. 262) defines register as "the language of group of people with common interests or jobs or the language used in situations associated with such groups". She provides the sports announcer talk as an example of register. Omitting the subject noun or pronoun, syntactic reduction by omitting verb to be, inversion of the normal word order, and using distinctive vocabulary are among the linguistic features of sports announcer register.

Institutional scientific register is another kind of language variation based on the participants' interests or vocations. Mayr (2008, p. 1-5) specifies the relation between language and institutions as a twoway relation. While language constitutes and shapes the institution; the institution creates and organizes the institutional language. Through language, institutions create their social reality by establishing patterns of understanding which are practiced and naturalized by the individuals: for example, the social reality of $\mathrm{WHO}$ is a dominated institution by scientific discoursal practices. Furthermore, Mayr (2008) believes that institutional register is a social practice between the discursive events, i.e., uses of language within and by the institution and the institution itself. Throughout the institutional register, institutional addressors reflect the power and ideology of their institutions. Institutional legitimization is the methodology used by different institutions to accomplish persuasion and consent. It follows that institutional power and ideology are 
communicated to the individuals. For example, institutional legitimization appears in what makes a citizen as good or bad; or what precautions should be followed to prevent Covid-19. Each institution is dominated by specific institutional register which is promoted by the institution throughout legitimizing social practices.

Roberts (2011, p. 81-84) states that the aim of studying institutional register is to explore the mechanism of the institutions' working; the experts' interaction; and the influence of power and knowledge on institutional discoursal practices. He classifies studies of institutional register into two categories. The first includes abstract theories interested with the processes that provide power to the institutions. Foucault's study (1981) of power relations within discourse is a prominent contribution to this category. He believes that institutions organize the power of language through regulations of the right to speak; discursive policing; and knowledge-based language. The second category is the conversational analysis of talk interaction. Drew and Heritage (1992) is among the representatives of this category. They analyze institutional register as task-oriented at least by one representative participant of an institution.

Thornborrow (2016, p. 1-5) adds that in conversational analysis, institutional register is characterized by restrictions on the participants' orientation towards tasks. Among these constraints are answering questions based on the ideology of the institutions. She adds that institutional contexts has specialized inferential frameworks which specify how questions and answers are delivered by the participants. Thomborrow specifies the characteristics of institutional register as follows:

(1) It is differentiated pre-inscribed talk that includes conventional participant roles, such as interviewer, interviewee, caller, and policeman.

(2) It is a symmetrical talk in terms of the participants' rights and obligations. For example, a magistrate has the right to ask questions while a defendant does not.

(3) It is a task-oriented talk where participants are governed by their institutional identities in achieving specific goals (5).

Roberts (2011, p. 84) comments on the asymmetrical nature of the institutional register by saying:

Typically these include: the degree of control over the content of talk; the allocation of turns; the special inferencing that experts has access to, the 
differential distribution of participants rights, and the very different impact that decisions have for the client or applicant.

Schubert (2016, p. 2- 4) states that the narrow definition of registers, which is adopted in sociolinguistic perspective, is confined to linguistic variation based on occupation, such as medicine, politics, and tourism. Therefore, the distinctive linguistic choices are reflected mainly in the vocabulary of texts. On the other side, the broad definition of registers reveals in Systemic Functional Linguistics (SFL) where registers are determined by specific situational features of given contexts. These situational features are field, i.e., the subject matter; tenor, i.e., the relation between the participants; and mode, i.e., the channel of communication.

Wardhaugh and Fuller (2015, p. 52-54) state that register, style, and genre are similar in analyzing linguistic use in particular contexts, or social situations. Nonetheless, they differ in the focus. Style focuses on the formality level as reflected in the speakers' contributions. This formality is specified according to certain factors, i.e., the social occasion, the participant's age, social position, and relation to one another. On the other hand, register is defined as "sets of language items associated with discrete occupational or social groups" (53). Finally, genre's focus is on the linguistic features associated with certain text types or kinds of literary or non-literary composition. For example, the news articles and advertisements have fixed forms and distinctive linguistic uses.

Biber and Conrad (2019, p. 31) define register as:

A linguist variety associated with both a particular situation of use and with pervasive linguistic features that serve important functions within the situation of use.

Wälchli and Szmrecsanyi $(2014$, p. 4) mention that Biber introduces two analytic terms for register analysis: microscopic variation, and macroscopic variation. The former is based on particularity, either in the analyzed features, or in the kind of variety under analysis. The later focuses on "the overall dimensions of variations within a set of varieties". Thanks to the work of Doglas Biber and others that register analysis shifted towards macroscopic dimension.

Teich (2012, p. 24-26) specifies two methods for register analysis based on the language of the targeted texts. The first method is to analyze monolingual texts by choosing a representative text of the targeted 
register to detect the most frequent lexico-grammatical features through applying a quantitative analysis and statistical techniques. The second method depends on analyzing texts written in different languages. This kind provides cross-linguistic comparison between registers in different languages. The first kind used is ESP while the second kind used in contrastive linguistics. Wälchli and Szmrecsanyi (2014, p. 11) define the notion of the "feature" as "morphosyntactic and lexical properties that can easily be identified in texts using automatic and semiautomatic retrieval technique".

According to Ferguson (1994) (as stated in Hernandez-Campoy 2019, p. 33-36) in sociolinguistic studies, register variation is "a communication situation". It recurs with different participants, communicative purposes and setting which influence the linguistic choices of the participants. These linguistic choices differ from one "communication situation" to another. He adds that in Hallidayan linguistics, register variation is attributed to "socio-situational contexts" which are responsible for producing language varieties used in specific occasions.

Finegan and Biber (1994, p. 37-39) classify situational frameworks into classificatory and descriptive. Classificatory frameworks of situational level are based on "discrete distinctions", such as the distinction between spoken and written text; and the distinction between the four modes of discourse. On the other side, descriptive frameworks of situational analysis depend on open-criteria, such as the context of situation; the four components of a text, i.e., participants, action, effects, and other related characteristics; and the criteria of field, tenor, and mood.

In their three-level approach for register analysis, Biber and Conrad (2019, p. 41-43) start with the situational level of analysis. They suggest seven elements as components of situational analysis. First, the participants in the text are divided into addressor, addressee, and onlookers. The addressor could be an identified, unidentified, or institutional entity. Age, gender, level of education, occupation, and social class are the influencing factors on the addressor's linguistic use. They state that although these factors are the basis of "social dialect variation", they are an essential part in the situational level of register analysis. Concerning the addressee, he/she could be one individual or enumerated number, e.g. readers of Shakespeare's plays. Finally, onlookers are only observers of the communication process, such as the audience in a theatrical performance. 
The relation between the participants is the second element in the situational level. It appears through three parameters: interactiveness; social roles and personal relationships; and the influence of shared knowledge. Interactivness refers to the interaction between the participants in the process of communication. It is classified into total interactivness as in face-to-face conversation; intermediate interactivness as in university lectures; and zero interactivness as in university catalog.

Regarding social roles and personal relationships, the participants could be socially equal or unequal as in classmates' conversations or doctor-patient exchange respectively. Finally, shared background knowledge is classified into general and specific. The general kind of knowledge appears in the shared knowledge of past events and identities between the addressor and addressee while the special background knowledge appears in shared fields of knowledge or specialty between the participants. For example, a conversation between two allergists or immunologists depends on special knowledge.

Tenbrink (2020, p. 143) believes that shared background knowledge is responsible for the inferences that participants can draw. For example, cultural background knowledge shared between the participants can create the same associations in the participants' minds. These associations are not literally spoken or written, they dwell in the participants' minds and impact on their contributions.

Channel, setting, and production circumstances are elements of the situational level. The channel element refers to the medium of language delivery as spoken or written and how the medium influence the lexicogrammatical features of the text. For example, using interjections and contractions are typical linguistic features of spoken language. The setting element refers to the physical time and place of the communication process, either as shared between the participants or not. Finally, the production circumstances are interpreted in the light of the setting. Sharing the same time and place among the participants deprives them of the chance of editing their contributions. On the other hand, written language does have the advantage of editing.

Communicative purpose (CP) refers to the aim or target of communication process. It is analyzed based on three parameters: the $\mathrm{CP}$ as general or specific; the factuality of information; and the epistemic stance. According to Biber and Conrad (2019, p. 45-46), general CPs could be narrating past events; describing current states of affairs; explaining information; arguing for opinion; or expressing personal 
attitude. General CPs could be combined in the same text. Moreover, switching between different CPs is another possibility in the same text, such as narrating a story in the context of Friday Sermon.

In contrast, specific CPs distinguish between sub-registers in the same text. Gray $(2015$, p. 7) specifies textbooks and research article as sub-registers of academic writing. They resemble the academic writing in the "informational purpose" and differ in the "non-linguistic features". These non-linguistic features include components such as the degree of specialty and the targeted reader. The content of research articles are more specialized and focused than textbooks; accordingly, research articles are intended to professional readers while textbooks are intended to non-professional readers. Factuality refers to the kind of information within the text as factual, imaginary, or combination of both.

Gray (2015, p. 62-63) discusses the elements of factuality under the headline "nature of data or evidence". She specifies three descriptive methods for data description: first, the kind of data as observed or nonobserved; second, the methodology which could be qualitative, quantitative, or mathematical; and finally the presentation of the evidence in the text. While qualitative analysis focuses on the prevalent topics or themes in the text; quantitative analysis depends on numerical data of certain phenomenon which could be presented statistically. Finally, mathematical analysis depends on mathematical calculations. For the presentation of the evidence in the text, it could be via descriptions, tables, charts, and figures.

Finally, the expression of stance has two forms: attitudinal and epistemic stance. The attitudinal stance appears in linguistic markers expressing the source of information or the personal attitudes and evaluations. For example, news reports include an expression such as "according to" to clarify the source of information; and an adverb, such as "fortunately" to express personal attitude. For the epistemic stance, it appears in the speaker's certainty or uncertainty of the content of a proposition. It appears in linguistic markers such as "the findings suggest that", "in general", and "it is possible that". Modality is one of the linguistic markers of epistemic stance. Vold (2012, p. 226) defines epistemic modality as:

Linguistic expressions that explicitly qualify the value of a propositional content ... Epistemic modality does not only encompass expressions of uncertainty, but also expressions of certainty (226). 
Biber et al. (2012, p. 853) classify epistemic linguistic markers into six kinds: doubt and certainty adverbials; actuality and reality adverbials; source of knowledge adverbials; adverbials of limitations, adverbials of viewpoints; and adverbials of imprecision. Each kind expresses a different attitude of the speaker towards the propositional content. Speaker's doubts could be expressed by using linguistic markers such as "probably", "maybe", "arguably", "I think". Speaker's certainty could be expressed by using "certainly", "of course", "decidedly", "incontestably", and "incontrovertibly".

Speaker's actuality is expressed by adverbials such as "actually", "in fact", while speaker's stance of reality is expressed by adverbials such as "truly", "in fact", and "really". Adverbials clarifying the source of information are "evidently", "apparently", "reportedly", and "reputedly". The source of information could be specific as in "according to" or authorized as in "X notes" with X referring to a proper noun. Adverbials of limitations which have the function of specifying the extent to which the proposition applies are "mainly", "typically", "generally", "largely", "in general", and "in most cases". Adverbials of viewpoint or perspective are "in our view", "from our perspective", and "in my opinion". Finally, adverbials of imprecision or what is known as hedges are "sort of", "about", "kind of", "roughly", and "so to speak".

The second kind of stance is personal attitudes and evaluations. It could be expressed by attitude adverbials such as "it is fortunate that"; "it is sensible that"; "hopefully"; "importantly"; "conveniently"; "wisely"; "as might be expected", "astonishingly"; and "quite rightly ".

The linguistic level proposed by Biber and Conrad (2019, p. 50-53) focuses on detecting the lexico-grammatical features which should be frequent and prevalent. One or two occurrences of a linguistic feature within the targeted register are not a proof of being a register feature. There should be many occurrences of the linguistic feature and a prevalent distribution throughout the targeted register to be a register features. This feature can occur in other registers; but it has the most frequent occurrences in the targeted register. Register features are the linguistic structures that occur with high frequency in the targeted register. On the other hand, register markers are linguistic structures that distinguish one register from the other registers. This is seen in "Ladies and Gentlemen" used at the beginning of spoken public speeches.

Based on Biber and Conard's approach for register analysis (2019, p. 64), functional analysis is the third level. It is the link between the 
situational level and the linguistic level. It clarifies why the distinctive linguistic features are associated with the distinctive situational features of a certain register. For example, using the first person pronoun "I" and the second person pronoun "you" in face-to- face conversation is functionally used by the speaker to refer to himself and the addressee, respectively.

This research covers a set of gaps, such as the lack of papers that focus on studying the characteristics of the institutional scientific discourse. The existing ones focus on studying one of these two sides, either the scientific or the institutional side (Freed (2015); Popova (2015); Gokhman (2019); Rusko (2014); A. Carusi and A. de Waard (2009). Moreover, this research uses the approach of Bieber and Conrad for register analysis which has not previously been applied to institutional scientific discourse to the best of the researcher's knowledge. In addition, it exploits the corpus tool of Antconc software 3.5.8 (2019) to study the institutional register of WHO which is one of several United Nations agencies specialized in the field of health. It is the directing and coordinating authority within the United Nations system in the field of health. The focus is on the linguistic characteristics of the register of WHO in the field of epidemics which has not been studied before to observe its contributions and limitations in addressing COVID-19.

\section{Analysis}

\section{Extract (1) from Sample (1)}

During our trip to China we were very impressed with the level of engagement of the Chinese government at all levels. Personally I think myself and the Director General have never seen the scale and commitment of an epidemic response at this level in terms of all of government involvement across all of the different arms of government with tremendous support being poured into Wuhan and Hubei from the central government with a highly organized emergency management structure. The challenge is great, but the response has been massive and the Chinese government deserves huge credit for that response and for the transparency in which they have dealt with this. Ryan. (2020 Jan 29). "Novel Coronavirus Press"

The previous extract is provided by the institutional addressor, i.e., Dr. Micheal Rayan, WHO executive director for health emergencies. His contribution is a response to the conference coordinator, Tarik Jasarevic invitation to brief on his visit to China. The journalists are institutional addressees as they represent different press agencies, i.e., 
institutions. They receive the data of the addressor's visit to China. Situationally, interactiveness is between two institutional participants, i.e., Dr. Micheal Rayan, WHO executive director for health emergencies and the WHO conference coordinator, Tarik Jasarevic. In this extract, the journalists do not participate in the talk interaction.

The relation between the institutional addressor and the institutional addressees is socially unequal because of the difference in professional affiliation and scientific specialty. The institutional addressor has some kind of authority and power which stems from his professional affiliation to WHO, the conference sponsor; and his scientific expertise as director for health emergencies. The institutional register is illustrated in the pronominal use of the first person plural pronoun and its possessive form in 2 times; and in the vocabulary of political associations in "government" 5 times; "response" 3 times; "Chinese" 2 times; and "level" in 2 times. Other vocabulary items of political associations are "challenge", "engagement", "commitment", and "involvement". The use of proper nouns "China", "Wuhan", and "Hubei" is another lexical feature of the institutional register.

In this extract, the participants share the same time and place. The institutional addressor's contributions include three CPs. Narrative CP appears in briefing his visit to China. The expressive CP appears in expressing the institutional attitude towards the Chinese response to the epidemic corona virus as deserving "huge credit". Finally, the persuasive $\mathrm{CP}$ appears in referring to the reasons of WHO appreciation of the Chinese response in "a highly organized emergency management structure" and "the transparency in dealing with the epidemic disease".

Grammatically, the institutional addressor functionally uses the past simple tense to achieve the narrative $\mathrm{CP}$ of past events, i.e., visiting chine in "During our trip to China we were very impressed". He resorts to the present simple to describe the dangerous state of affairs in "the challenge is great", and to argue for the institutional opinion towards the Chinese government in "the Chinese government deserves huge credit". The present perfect is used by the institutional addressor in order to argue for the Chinese mastery in controlling the epidemic corona virus. This is clear in "the response has been massive" and in" I think myself and director general have never seen the scale and commitment of an epidemic response at this level". Lexically, the institutional attitude of WHO towards the Chines response to corona virus is communicated by positive adjectives such as "impressed", "tremendous", "highly", "huge", 
"great", "massive", "organized" which show the appreciative and supportive attitude of WHO to China.

On the phrase level, the prepositional phrase (PP) is the most commonly used kind in this extract with frequency of 13 times. The institutional addressor uses the PP to focus on the epicenter of corona virus in "engagement of the Chinese government", "tremendous support ...into Wuhan and Hubei" and in "trip to China". The PP post-modifies "engagement", "support", and "trip" respectively. It is functionally used to focus on the epicenter of corona virus.

The complex NP is the distinguishing feature in this extract. The institutional addressor uses the complex NP to describe the Chinese government response to the corona virus in "With the level of engagement of the Chinese government at all levels", "of an epidemic response at this level"; and in "with tremendous support being poured into Wuhan and Hubei from a central government with a highly organized emergency movement structure".

On sentential level, this extract is characterized by using long sentences. $S_{2}$ is structured of 57 lexemes; likewise, $S_{3}$ is structured of 31 lexemes. The complete extract is organized of three sentences.

\section{Extract (2) from Sample (1)}

We'll take them from the bottom up in terms of experts from China, Taiwan, or Taipei Municipality. We have Taiwanese experts involved in all of our consultations - the clinical networks, lab networks, and others - so they're fully engaged and fully aware of all of the developments in the expert network [unclear] and Maria can speak to that and Maria can speak to you in terms of the death. $2 \%$ case fatality is still a tough case fatality when you compare it to the case fatality for seasonal flu or other things. It's the interaction between the attack rate or the transmissibility of the virus and the severity that give you the outcome. Ryan. (2020 Jan 29). "Novel Coronavirus Press"

The above extract is Dr. Rayan's contribution in response to the journalist's questions about a variety of issues. The journalist inquiries about the effect of the countries' evacuation of their citizens from China, their isolation, and the fatality rate caused by Covid-19 in relation to Dr. Ryan's previous comment. The final inquiry is about the inclusion of 
Taiwan in the Emergency committee (EC) and the spread of the virus in Taiwan in case of excluding Taiwanese experts from participating in the EC.

Situationally, the interactiveness element appears in the pronominal use of the second person pronoun in "when you compare it to", "Maria can speak to you" and "severity that give you the outcome". The institutional addressor uses the second person pronoun ostensibly to direct his contribution to the journalist; but genuinely to express WHO ideology to all the attending journalists who, in return, will spread this information through their media institutions.

Dr. Ryan's institutional identity is reflected in his use of the institutional register. It is illustrated in the pronominal use of the first person plural pronoun in 3 times: "we have Taiwanese experts involved in all of our consultations" and in "we'll take them from the bottom up". The institutional addressor functionally uses the pronominal feature to express the ideology and policies of WHO. The order of responding to the questions reflects that the ideology of WHO is the first priority for the institutional addressor, i.e., including Taiwanese experts in the EC. Another pronominal use is the third person plural pronoun in "they are fully engaged in the entire expert network" which is functionally used to refer to Taiwanese experts in WHO.

Proper nouns are another lexical feature used functionally by the institutional addressor to express WHO ideology. The proper noun "China" is used to focus on the epicenter of Covid-19; likewise, the adjectival use of "Taiwanese" in "we have Taiwanese experts in all of our consultations" negates the exclusion of Taiwan from participating in the EC. It is a task-oriented use of language by the institutional addressor.

The institutional addressor has a higher social status than the journalist based on his institutional affiliation and his scientific knowledge which appears in using lexemes of scientific associations such as "virus", "transmissibility", "tough", "case", "expert", "fatality" and "seasonal flue".

Situationally, the institutional addressor communicates expressive and persuasive purposes. The expressive purpose appears in clarifying that WHO has Taiwanese experts in its consultations and that the $20 \%$ case fatality is a tough case. The persuasive purpose appears in his justification of the $2 \%$ fatality rate as a tough case in "It is the interaction between the attack rate or the transmissibility of the virus and the severity that give you the outcome". 
On the phrasal level, the complex NP and the PP are the most frequent kinds. They are functionally used by the institutional addressor to communicate his expressive purpose in "Taiwanese experts involved in all of our consultations" where the head noun "experts" is post-modified using the past participle adjective "involved" and the PP "in all of our consultations" Similarly, the persuasive purpose is communicated via complex NPs in "the transmissibility of the virus" and in "the severity that give you the outcome". In the former, the head noun "transmissibility" is post-modified by the PP "of the virus" while in the later the head noun "severity" is post-modified using the relative thatclause.

On the sentential level, the use of long sentences prevails. The longest is the final sentence, sentence (4) which includes 51 lexemes. Based on the Word List of this extract, the most frequent lexemes are functional words, followed by nominal use then pronominal use. The nominal use is characterized by scientific associations, such as "case" , "fatality" , "experts" , "networks" each reiterates in 3 times. In addition; each of the lexemes "flue", "interaction", "lab", "seasonal", "severity", "transmissibility", and "virus" is used once.

\section{Extract (3) from Sample (2)}

Thank you. So we mentioned yesterday in our sitrep that we will be launching this global novel coronavirus clinical characterization case reporting form and this is our attempt to work with countries that are treating patients to have a standardized way to collect information about the clinical presentation, the signs and symptoms that they may have, laboratory testing, and how these patients are cared for. It's very important that we collect this in a standardized way so that we can better characterize what infection looks like, what disease looks like by being infected with this virus. Kerkhove. (2020 Jan 29). "Novel Coronavirus Press"

The addressor is identified as Dr. Maria Van Kekhave, Head of emerging diseases and zoonosis. Her contribution is a response to Dr. Rayan's invitation to discuss the data-sharing platform. The interactiveness element appears in-between two institutional addressors, i.e., Dr. Rayan and Dr. Kerkhove. Linguistically, this is reflected in using the second person pronoun "you" by the institutional addressor to thank the addressee in "thank you". The journalists who represent different press agencies are the on-lookers. They listen to the institutional addressor's contribution without participating in the talk interaction. 
The shared background knowledge appears in the announcement by WHO concerning setting up a novel corona virus data-sharing platform. Being a spoken text variety, the institutional addressor does not have time to revise, edit, or delete information as the participants share the same time and place, i.e., "a UN building in Geneva at 7:30 Geneva time".

The institutional addressor communicates expository CP. She explains the aims of the data-sharing platform of the global novel corona virus. Linguistically, the expository aim is achieved by the to-infinitive in 3 times: in "to work with countries", "to have a standardized way", and in "to collect information about". Long sentences are another distinctive grammatical feature to accomplish the expository $\mathrm{CP}$, most notably in $\mathrm{S}_{2}$ which is structured of 63 lexemes. The addressor dedicates the past simple tense to emphasize the platform of novel corona virus in "so we mentioned yesterday"; while the continuous future in "we will be launching" expresses WHO future efforts to control corona virus. The institutional addressor's stance of uncertainty about corona virus symptoms appears in the modal verb "may" in "symptoms that they may have" and the phrasal verb "looks like" in "what infection looks like".

On the phrase level, the speaker uses the complex NPs in "this global novel corona virus clinical characterization case reporting form" in $\mathrm{S}_{2}$. The speaker describes the head noun "form" by the pre-modifiers "this", "global novel corona virus", "clinical characterization", and "case reporting". Moreover, in "countries that are treating patients" the postmodifier is the relative clause "that are treating patients". Likewise, in "information about clinical patients" and in "symptoms that they may have", the pre-modifiers are the prepositional phrase "about clinical patients" and the relative clause "that they may have", respectively.

The addressor's institutional identity is reflected in the pronominal use of the first person plural pronoun in 4 times: "we mentioned", "we will be launching", "we collect", and in "we can better". The numerical superiority of the nouns over the pronouns is characterized by using lexemes of scientific associations where the scientific register directed to the public appears in "disease", "laboratory", "testing", "information", "characterization", "presentation", "symptoms", "patients", "virus", "corona", and "signs".

\section{Extract (4) from Sample (2)}

Yes. Just to complement what Mike has said, the rapid sharing... when we say rapid, we mean days. The availability of having a full genome 
sequence of a novel virus available to the public to be able to develop diagnostics to be able to diagnose patients in other countries is unprecedented. The world is on alert and the fact that they had these sequences available made them able to use PCR testing and use full genome sequencing to identify these cases quickly. So this is why we are seeing cases and why the evolution of this is so quick and this is a positive. Just to say, with regards to the virus-sharing, it is essential that viruses are shared so that the further development of diagnostics and serologic assays, so that the further development of therapeutics and vaccines can continue. Kerkhove. (2020 Jan 29). "Novel Coronavirus Press"

This extract is the contribution of Dr. Kerkhove who is given the right to speak by Dr. Rayan. The interactiveness element is confined to two institutional addressors; and the journalists are just on-lookers. The given turn is indirectly delivered by Dr. Rayan in "May be Maria can add on the sequence'.

The institutional addressor has expository CP. She explains the benefits of sharing information about the genetic sequence of Covid-19. Sharing genetic sequence, as she explains, leads to the diagnosis of infected cases and exploration in therapeutics and vaccines. Lexically, this is achieved by using the vocabulary of scientific associations that relates to the expository purpose. This is clear in the use of lexemes such as "sharing", "virus", "rapid", "available" and "availability", "cases", "development" "diagnostics" and "genome". Each of these lexemes occurs 2 times. Grammatically, the use of to-infinitive is functionally exploited to express the expository purpose in "to be able to develop diagnostics"; "to be able to diagnose patients"; "to explain the importance

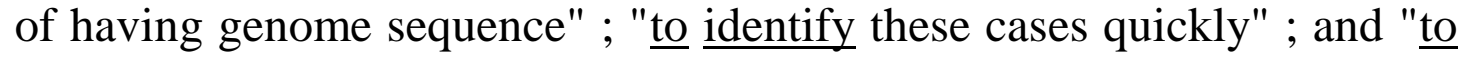
use PCR testing".

The relation between the two institutional addressors is socially equal. This is attributed to their similar institutional identities, i.e., doctors in WHO and their specialty, i.e., medical expertise. On the other side, the relation between the institutional addressor and the on-lookers, i.e., the journalists is socially unequal. The source of the social inequality stems from institutional affiliation and scientific specialty which is reflected in the scientific vocabulary: "evolution", "virus", "diagnostics", "vaccines", "serologic", "genome", and "therapeutics".

The institutional identity of the addressor appears in the pronominal use of the first person plural pronoun in 3 times: "we are seeing cases", "we mean days" and in "we say rapid". The referent of "we" is the World 
Health organization. The second frequent pronominal use is the third person plural pronoun "they" in "they had these sequences" and in "made

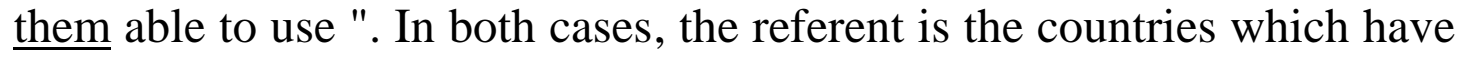
the genetic sequence of Covid-19 and accordingly can apply the PCR in the virus diagnosis.

The general shared background knowledge appears in "the rapid sharing ...when we say rapid, we mean days". Based on the context of utterance, the ellipted part is "of novel corona virus". The institutional addressors and the journalists share the general background knowledge that the intended sharing is of the genetic sequence of Covid-19 although not stated literally by the institutional addressor. Specific background knowledge appears in the institutional addressor's use of the adverb "yes" in response to Dr. Ryan's "it is important to understand the extra advantages that virus sharing gives you over sequence sharing". Both of the institutional addressors share the specific knowledge of the importance of genome sequence of Covid-19 to explore a vaccine.

The descriptive purpose is represented in the description of the current state in the world in "the world is on alert "; the transmission of the virus in "the evolution of this is so quick". Linguistically, simple tense of the verb either the present or the past is used to communicate the descriptive purpose. Notably, simple present tense is used to clarify the institutional ideology of WHO in "we say", "we mean", and in "the availability to.... is unprecedented ".

Sharing the same time and place between the participants in this extract deprives the addressor of editing and deleting. Therefore, an incomplete grammatical structure appears in "the rapid sharing..."

Linguistically, complex NPs and PPs are the most recurrent kind of phrases. This is seen in examples such as "sequence of a novel virus"; "development of diagnostics"; "the availability of having a full genome"; "the evolution of this"; and "patients in other countries". The underlined prepositional phrases are used as post-modifiers of the nouns "sequence"; "development"; "availability"; "evolution "; and "patients" respectively.

On the sentential level, this extract is composed of 5 long sentences. Sentence (2) is composed of 33 lexemes, sentence (3) is composed of 31 lexemes and sentence (5) is composed of 36 lexemes.

The institutional addressor uses the certainty stance to express the existing scientific issues using the NP "the fact" in" the fact that they had these sequences available ...". Another use of certainty stance appears in 
"It is essential that viruses are shared ..." The institutional addressor expresses his certainty of the importance of genome sequence sharing to explore Covid-19 ; and information sharing about viruses in general to develop therapeutics and vaccines. In both instances, the certainty stance is expressed in the relative clause and the marker of certainty is a NP. The second kind of stance is the source of knowledge stance. It appears in "what Mike has said".

\section{Extract (5) from Sample (3)}

Maybe to add one more on that, as you know, the capacity of the emergency program in WHO especially since Ebola in 2014 has increased, thanks actually to Margaret Chan, who started the reform and we built on that, but we also believe that we need to build it and upgrade it constantly. We are learning and learning from day-to-day events we get and building it on a constant basis will be very important. Thank you. Ghebreyesus. (2020 Jan 29). "Novel Coronavirus Press"

The addressor is identified as Dr. Tedros Ghebreyesus, WHO director-general. His contribution is an additional commentary on WHO readiness to control the novel corona virus as he states in "Maybe to add one more on that". The institutional addressor directs his contribution to the audience of attending journalists in the conference. The participants share the background knowledge about WHO efforts in confronting Ebola virus in Congo as it appears in the journalist's contribution, i.e., "Dr. Ghebreyesus, WHO is also dealing with Ebola in Congo, with other crises". Although the journalist does not literally mention corona virus in his question, i.e., "Is WHO ready to deal with this new big challenge?", the institutional addressor and the attending journalists understand that the proximal demonstrative "this" refers to the novel corona virus.

The institutional addressor has expository $\mathrm{CP}$ concerning the capacity of the WHO emergency program. To communicate his purpose, the institutional addressor uses a long sentence composed of 53 lexemes. He uses the present perfect in "has increased" to show that the increase in the capacity of WHO emergency program started in 2014 and is still increasing until the present time.

In addition, the speaker uses the simple past tense to inform about the reform in WHO as "started" in the past; and the present simple to delineate the future aims of WHO in "we need to build it and upgrade it". The institutional addressor seeks to tell the audience that the reform in WHO has started in the past by Margaret Chan as the launcher of the reform program, and it will develop in the future. 
On the phrasal level, the institutional addressor functionally uses complex NPs to discuss the increase and reform in WHO emergency program. This is clear in "the emergency program in WHO" where the head noun "program" is pre-modified by the NP "the emergency" and post modified by the PP "in WHO".

The institutional addressor's use of the first person plural pronoun reflects the institutional policy of WHO: "we built on that", "we also believe", "we need to build it", "learning from day-to-day events we get", and in "We are learning". He explains WHO policy in the reform program. In addition, he uses the second person pronoun "you" to emphasize the development of the emergency program in WHO as a well-known fact in "as you know, the capacity of the emergency program in WHO ... has increased". This extract is characterized by a nominal use more than a pronominal one. The nouns used have scientific associations such as "emergency", "Ebola", "capacity", and "program". These lexemes reveal the scientific register as a linguistic device in achieving the institutional aims.

\section{Extract (6) from Sample (3)}

As you know, we have just returned from China and yesterday we had the opportunity to meet with President Xi Jinping, Minister of Health Ma Xiaowei, and Minister of Foreign Affairs Wang Yi. Prior to my visit, I was in almost daily contact with Minister Ma to discuss the response to the outbreak and how WHO can support because we need to focus on the epicentre of the outbreak. Managing the outbreak at the epicentre helps us from the outbreak spreading to the rest of the world. During my visit we had a series of very candid discussions based on mutual understanding. Our discussions focused on continued collaboration on containment measures in Wuhan, public health measures in other cities and provinces, conducting further studies on the severity and transmissibility of the virus, and sharing data and biological material. Ghebreyesus. (2020 Jan 29). "Novel Coronavirus Press"

The previous extract is provided by Dr. Ghebreyesus, the directorgeneral of WHO as a response to the conference coordinator's offer to speak in "I'll give the floor now to Dr. Tedros". The interactiveness element unfolds into two sides. The first one is between two institutional addressors, i.e., Dr. Ghebreyesus and the conference coordinator. The second side is between Dr. Ghebreyesus and the attending journalists who receive, watch, and listen to Dr. Ghebreyesus's contribution. 
The addressor's institutional identity appears in his professional affiliation to WHO as the director-general. It is reflected in the CPs he is trying to communicate: descriptive and expository. His descriptive purpose appears in his briefing on his visit to China, the epicenter of Covid-19. Linguistically, the descriptive CP is communicated by the past simple tense in "returned", "focused", and "had". In addition, the descriptive $\mathrm{CP}$ is communicated by recurrent lexemes of political associations such as "discussions", "visit", each of which occurs twice, and "meet", "opportunity" "contact" and "discuss" each used once. Proper nouns of Chinese officials are another linguistic device exploited by the institutional addressor in "Xiaowei","Xi jinping " and "wang Yi".

The expository $\mathrm{CP}$ of the institutional addressor is shown in his expression of the exerted efforts by WHO to confront Covid-19. Linguistically, the expository $\mathrm{CP}$ is communicated by lexemes of scientific associations such as "biological", "severity", "transmissibility", "epicenter" and "measures". The to-infinitive and the pronominal use are another linguistic devices that are functionally used to accomplish the expository CP. To-infinitive structure appears in examples such as "to discuss the response", " To focus on the epicenter ", and "to meet with president Xi". The previously mentioned uses of to-infinitive reveal the exerted efforts by WHO in controlling Covid-19. The pronominal use is shown in the first person plural pronoun as the most recurrent pronominal use. It appears in examples such as "we had a series of very candid discussions ", "we had the opportunity to meet', "we had just returned from China", "we need to focus on the epicenter" and in "helps us from the outbreak".

The shared background knowledge appears in "As you know, we have just returned from China" The participants share the background knowledge that Dr. Ghebreyesus visited China because it is the epicenter of Covid-19. Moreover, they know that his visit to China is not personally motivated, but institutionally motivated as Dr. Tedros is WHO directorgeneral.

The relation between the participants is socially unequal. This is attributed to the institutional identity of the speaker, and his scientific specialty. The institutional register is reflected in using political lexemes such as "president", "minister of health", "minister of foreign affairs", and in using Chinese proper names of Chinese officials. The scientific register appears in using lexemes of scientific associations such as "severity", "transmissibility", "health", "outbreak", "epicenter", "measures", and "biological". 


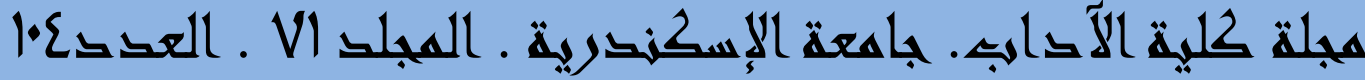

On the phrasal level, the complex NP and the PP are the most recurrent kind. This is clear in examples such as "minister of foreign affairs", "minister of Health", "studies on the severity", "measures on Wuhan", "transmissibility of virus", "response to the outbreak" and "collaboration on containment measure". In these examples, the PP functions as post-modifier of the head nouns "minister", "studies" "measures", "transmissibility", "response", and "collaboration" respectively. On the sentential level, long sentences are the most prominent feature. This extract is composed of 5 sentences: sentence (1) is composed of 33 lexemes, sentence (2) and (5) each are composed of 36 lexemes.

\section{Discussion}

In the three samples under analysis, the participants are identified institutional addressors. Their institutional identity appears in their institutional positions in WHO: Dr. Mike Ryan is WHO Executive Director; Dr. Maria Van Kerkhove is the Head of emerging diseases and zoonosis; and Dr. Tedros Ghebreyesus is the Director-General of WHO. The other detected category of institutional addressors is the journalists. They represent specific institutions, i.e., news agencies such as French public radio, France 24 and the Lancet, Voice of America, and China's Xinhua News Agency. They are designated by their first names in "We will have three more questions here from the room. Jamil, Gabriela, and then... "; in "First Stephanie, then Nina, then John, and then we will go online"; and in " we promised John and then we will go to a couple of questions from journalists watching us online. John, please". Likewise, the institutional addressors affiliated to WHO are designated by their first names preceded by the academic title "Dr".

Most of the contributions are provided by the institutional addressors, i.e., the scientists affiliated to WHO. The scientific register is affected by the scientists' specialty and professional affiliation to WHO. This is detected in the distinctive linguistic characteristics of their contributions. For example, the pronominal use of the first person plural pronoun occurs 213 times as table (1) reveals: 


\begin{tabular}{|c|c|c|}
\hline \multicolumn{3}{|c|}{ 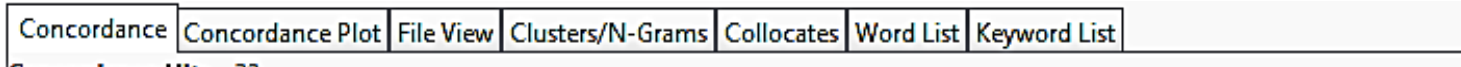 } \\
\hline \multicolumn{3}{|c|}{ Concordance Hits 32} \\
\hline Hit & KWIC & File \\
\hline || 1 & bnward spread, making sure that we are addressing critical unknowns. Li & sample 2-txt \\
\hline || 2 & hat from the Chinese perspective. We are already working with Chinese & sample 1-.txt \\
\hline | 3 & are supporting us in this. We are also working to ensure & sample 1-.txt \\
\hline 4 & also very concrete reasons why we are appreciating China: one, identifyi & sample 3.txt \\
\hline ||5 & evolution of this epidemic. So we are asking our member states & sample 1-.txt \\
\hline 6 & to respond to this outbreak. We are at an important juncture & sample 1-.txt \\
\hline || 7 & regional director Dr Moeti, and we are concerned for countries in & sample 1-.txt \\
\hline 8 & still with travel to Wuhan. We are continuing to learn more & sample 1-.txt \\
\hline || 9 & .DG? On the first one, we are currently working with at & sample 1-.txt \\
\hline 10 & criteria have been met and we are dealing with a & sample 1-.txt \\
\hline |11 & from WHO to send, but we are discussing what skillsets we & sample 3.txt \\
\hline 12 & seriousness. This is exactly what we are doing. Now more than & sample 3.txt \\
\hline 13 & lab and another expertise and we are & sample 1-.txt \\
\hline $\mid 14$ & virus cases tomorrow elsewhere. We are helping other countries to & sample 1-.txt \\
\hline 15 & gency Committee tomorrow and we are hoping to receive that & sample 1-.txt \\
\hline 16 & it and upgrade it constantly. We are learning and learning from & sample 3.txt \\
\hline 17 & of China. This is something we are looking for. This is & sample 2-.txt \\
\hline 18 & China in three countries, which we are monitoring very closely. The & sample 3.txt \\
\hline 19 & may need our support. So we are preparing for that. During & sample 3.txt \\
\hline ||20 & for all countries and what we are providing guidance for is & sample 2-.txt \\
\hline 21 & the day-to-day reporting. We are receiving a detailed daily & sample 1-.txt \\
\hline 22 & transmission in three countries, we are reconvening the $\mathrm{EC}$ to & sample 3.txt \\
\hline 23 & quickly. So this is why we are seeing cases and why & sample 2-.txt \\
\hline 24 & epidemics and natural disasters; we are seeing the impacts of & sample 1-.txt \\
\hline 25 & Eenters that become established. We are sharing information, guid & sample 1-.txt \\
\hline 26 & you. Thank you. On financial, we are talking to partners and & sample 3.txt \\
\hline 27 & ppurred countries into action and we are very grateful for that & sample 1-.txt \\
\hline 28 & the overall global expertise ${ }_{f}$ but we are very grateful that China & sample 1-.txt \\
\hline 29 & in any way possible. So we are working on that. On & sample 3.txt \\
\hline 30 & front-line health workers. Yes. We are working very hard on & sample 1-.txt \\
\hline 31 & countries to plan and purchase, we are working with a broad & sample 1-.txt \\
\hline 32 & up its own supplies and we are $\times 85$ as I said, & sample 1-.txt \\
\hline
\end{tabular}

Table 1: we-are structure

The institutional addressors in the three samples are functionally using the first person plural pronoun to convey descriptive or expository communicative purposes. As shown in table (1), the scientists use the "we-are structure" to express one of two points: the currently exerted institutional efforts of WHO as in 1, 2, 3, 8, and 14; or the institutional attitude towards China and the Chinese government in 2 and 27. Figure (1) shows that the highest prevalence of the "we-are structure" occurs in Sample (1); followed by Sample (3) then Sample (2). 


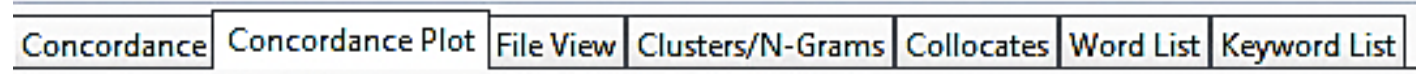
Concordance Hits $32 \quad$ Total Plots (with hits) 3

Plot: 1 FLE: sample1-.tat

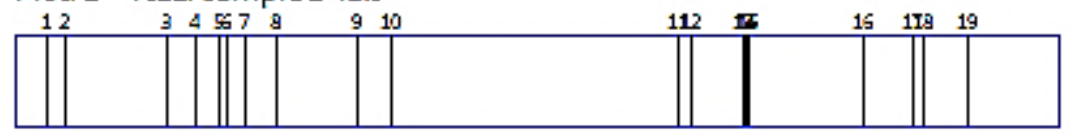

Hits: 19

Chars: 29732

Plot: 2 FlLE: sample 2-.txt

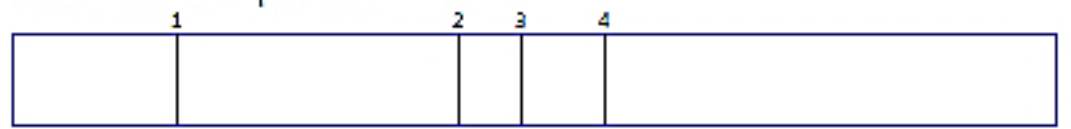

Hits: 4

Chars: 6985

Plot: 3 FLE: sample 3.txt

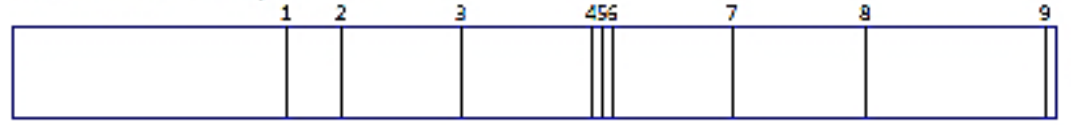

Hits: 9

Chars: 13194

Figure (1): Concordance Plot of we-are structure

The second functional use of the first person plural pronoun is to express future possible institutional aims. This is achieved by five linguistic structures. Tables (2) and (3) show the addressors' use of the "we- will structure" and the "we-may structure" to express the future aims of WHO. It is a task-oriented register by the institutional addressors to express the future policy of WHO towards the novel coronavirus. Both structures have equal frequency of 5 times. The highest prevalence of these linguistic structures appears in sample 3 as figure (2) and (3) indicate. The use of "we-may structure" reveals the constraints imposed on the institutional addressors. As representatives of WHO, they cannot give promises, therefore they use the modal "may" to reveal the probability of future actions.

\begin{tabular}{|c|c|c|}
\hline Concordanc & 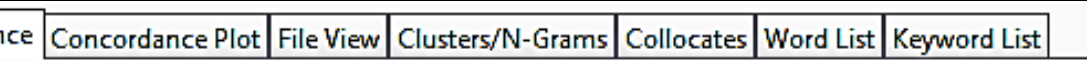 & \\
\hline \multicolumn{3}{|c|}{ Concordance Hits 5} \\
\hline Hit & WIC & File \\
\hline 1 & ned yesterday in our sitrep that we will be launching this global novel & sample 2-.txt \\
\hline 2 & . As far as WHO is concerned, we will do the right things. For & sample 3.txt \\
\hline 3 & were part of our mission. Then we will put together others from WHO & sample 3.txt \\
\hline 4 & proves, as detection improves, we will see people identified on the & sample 2-txt \\
\hline 5 & bly transparent in this regard. We will take them from the bottom & sample 1-txt \\
\hline
\end{tabular}

Table 2: we-will structure 


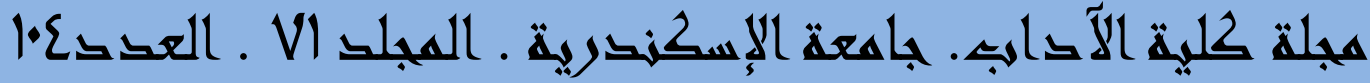

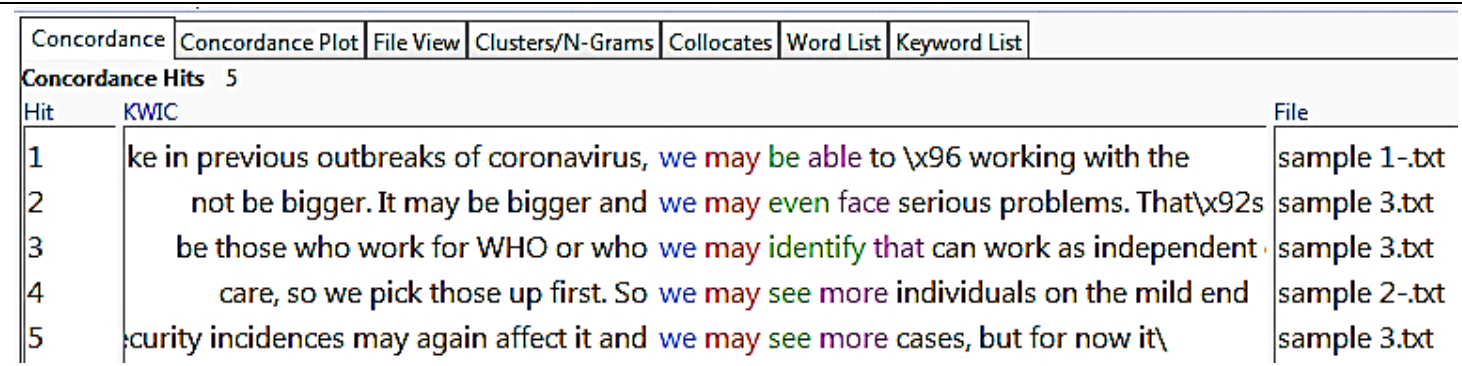

Table (3): we-may structure

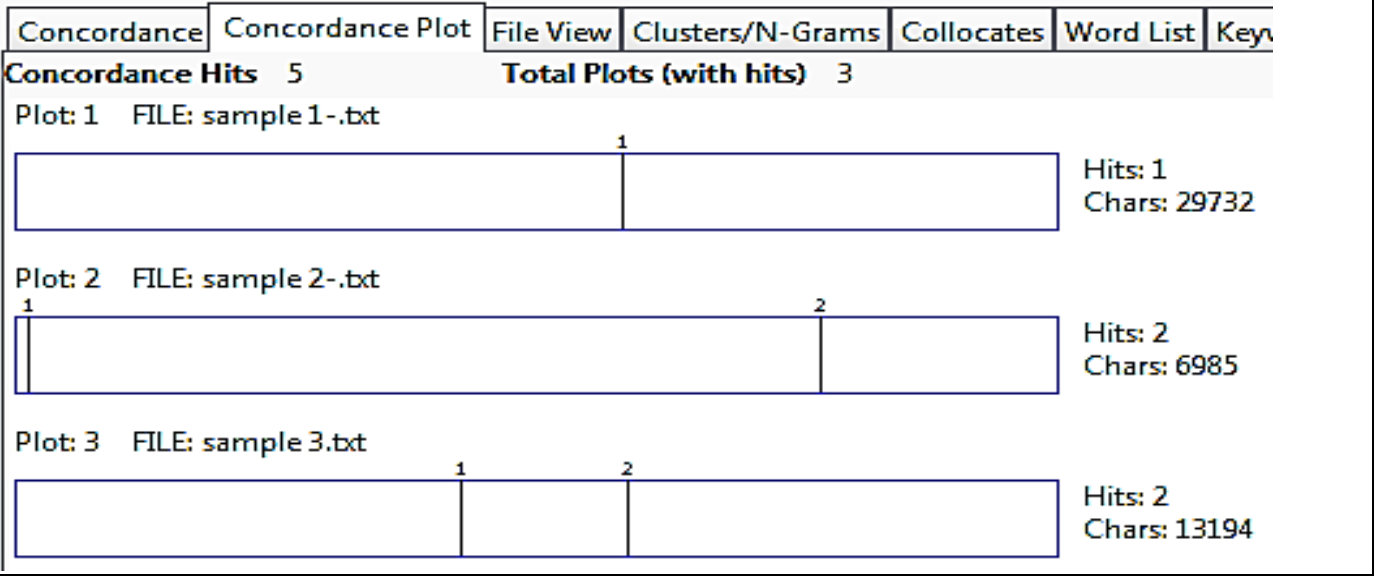

Figure (2): Concordance plot of we-will Structure

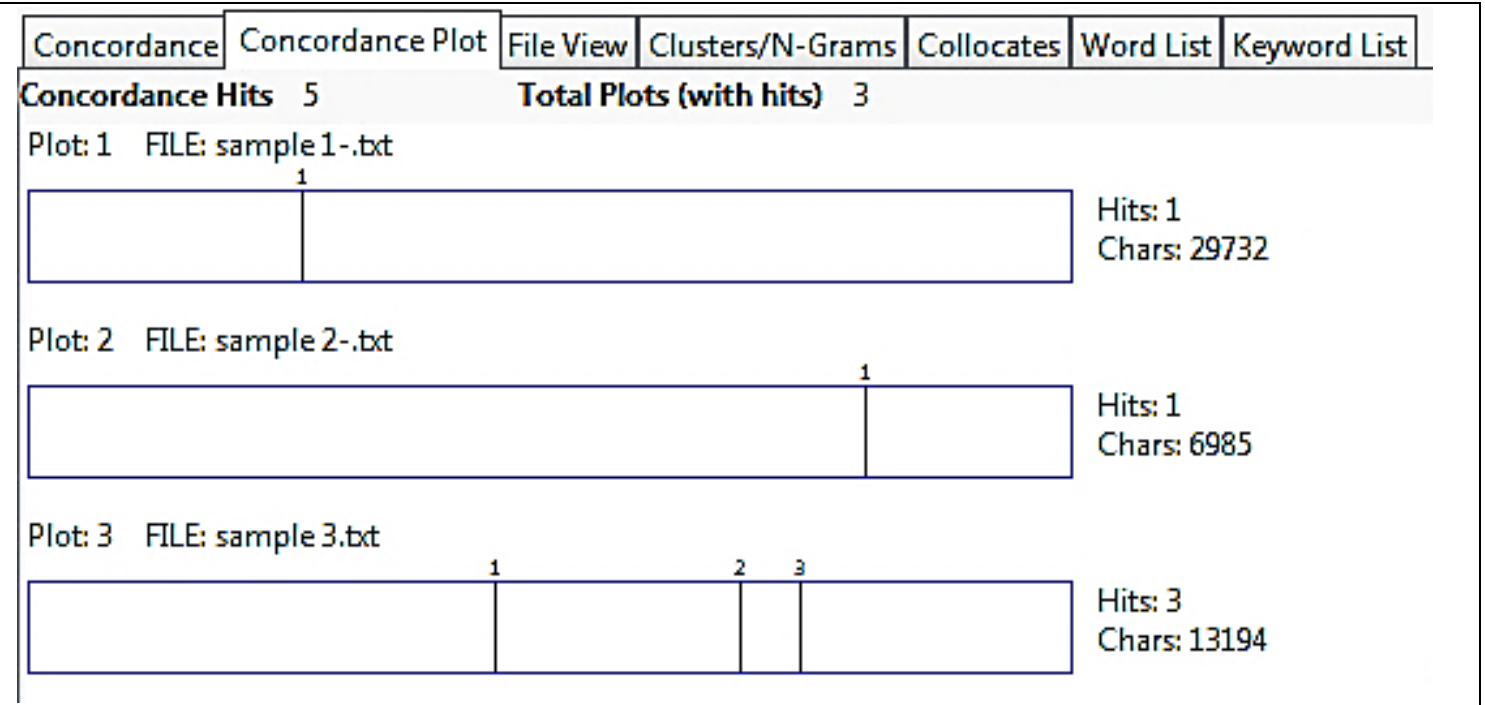

Figure (3): Concordance plot of we-may Structure

The "we-can structure" and the "we-need structure" achieve the same expository purpose, i.e., revealing the possible future aims of WHO. Table (4) reveals that "we-can structure" has a frequency of 13 times. 
They prevail in the three samples with the highest prevalence in sample (1), followed with sample (2), and then sample (3), as figure (4) clarifies.

\begin{tabular}{|c|c|c|}
\hline \multicolumn{3}{|c|}{\begin{tabular}{|l|l|l|l|l|l|l|} 
Concordance & Concordance Plot & File View & Clusters/N-Grams & Collocates & Word List & Keyword List \\
\end{tabular}} \\
\hline \multicolumn{3}{|c|}{ Concordance Hits 13} \\
\hline Hit & KWIC & File \\
\hline 1 & with Chinese experts to learn as much as we can about this disease in order that other & sample 1-.txt \\
\hline 2 & collect this in a standardized way so that we can better characterize what infection looks & sample 2-.txt \\
\hline 3 & studies that need to take place so that we can better understand and characterize the 1 & sample 2-.txt \\
\hline 4 & to share that surveillance data with us so we can build a proper global picture of the & sample 1-.txt \\
\hline || 5 & right from the 31st of January [sic]. So we can come back to you afterwards with some & sample 1-.txt \\
\hline || 6 & stand back and say, well, there is nothing we can do, this is spreading out of control, & sample 1-.txt \\
\hline | 7 & $h$ in advance of those dates you mentioned. We can go through some of the data with & sample 1-.txt \\
\hline 8 & afternoon to ensure that we receive that so we can have a parallel analysis in advance of & sample 1-.txt \\
\hline || 9 & eeing today, is influencing the way in which we can manage potential coronavirus cases ton & sample 1-txt \\
\hline $\mid 10$ & I can add to that is (dots) what we can say to date is how many people & sample 2-.txt \\
\hline 11 & , but when you speak about that in general, we can see issues with transparency around the & sample 1-.txt \\
\hline 12 & ost organized and standardized format that we can. So I will ask Maria to speak & sample 1-.txt \\
\hline 13 & $t$ China is doing very serious measures and we can $x 92 t$ ask for more. We understand & sample 3.txt \\
\hline
\end{tabular}

Table (4): we-can structure

\begin{tabular}{|c|c|c|c|c|c|c|}
\hline Concordance & Concordance Plot & File View & Clusters/N-Grams & Collocates & Word List & Keyword List \\
\hline
\end{tabular}

Plot: 1 FLE: sample1-.txt

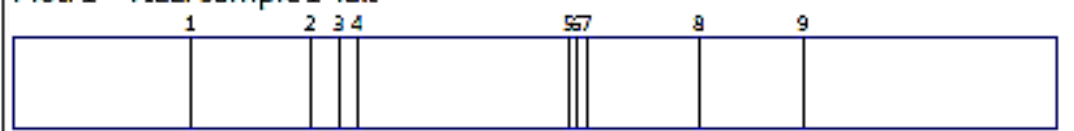

Hits: 9

Chars: 29732

Plot: 2 FLE: sample 2-.txt

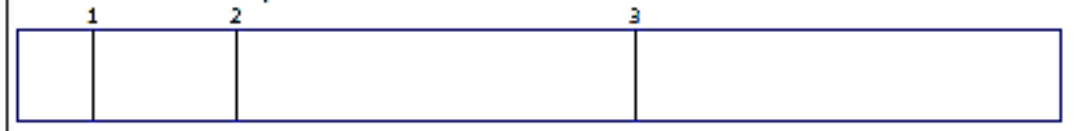

Hits: 3

Chars: 6985

Plot: 3 FlE: sample 3.txt

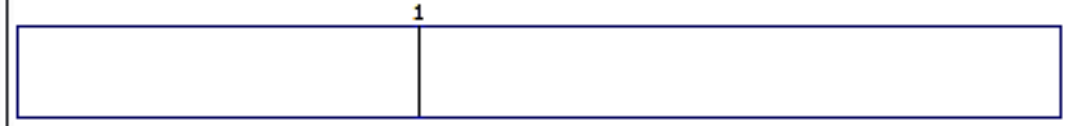

Hits: 1

Chars: 13194

Figure (4): Concordance plot of we-can Structure

The "we-need structure" has a frequency of 14 times, as table (5) reveals. The scientists show that the aims of their institution include the countries' preparation for infection; having information about infected cases; sharing data by member states; working with partners in the media; and focusing on the epicenter of the virus outbreak. The "we-need structure" prevails in the three samples as figure (5) reveals. The highest prevalence is in sample (1), followed by sample (3), then sample (2). 


\begin{tabular}{|c|c|c|}
\hline Concordance & 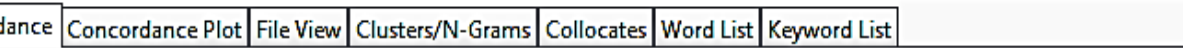 & \\
\hline \multicolumn{3}{|c|}{ Concordance Hits 14} \\
\hline Hit & KWIC & File \\
\hline 1 & we are looking for. This is something that we need countries to prepare for and make st & sample 2-.txt \\
\hline 2 & d second generation outside of Wuhan. What we need is more information on that in terms & sample 2-.txt \\
\hline 3 & ata-sharing platform. There is much data that we need member states to share with us and & sample 1-.txt \\
\hline 4 & we find a way to make that happen? We need partners in the media to work with & sample 1-.txt \\
\hline 5 & for having that concern, but I do think we need to also focus on what to do. & mple 1-.txt \\
\hline 6 & x96 to examine what we know the questions we need to answer ${ }_{r}$ and who is best placed & sample 1-.txt \\
\hline 7 & collaboration of the public and private sector. We need to be able to leverage that. So & sample 1-.txt \\
\hline 8 & built on that, but we also believe that we need to build it and upgrade it constantly. & sample 3.txt \\
\hline 9 & legative and for the positive. Therefore, what we need to do is decide collectively as nations & sample 1-.txt \\
\hline 10 & that are designed to stop the virus. So we need to focus not on where the peak & sample 1-.txt \\
\hline 11 & to focus not on where the peak is. We need to focus on our actions in the & sample 1-.txt \\
\hline 12 & putbreak and how WHO can support because we need to focus on the epicenter of the & sample 3.txt \\
\hline 13 & have to address that much more, but also we need to reflect and celebrate the global co & sample 1-.txt \\
\hline 14 & to send, but we are discussing what skillsets we need to send. On involving other countrie؛ & sample 3.txt \\
\hline
\end{tabular}

Table (5): we-need structure

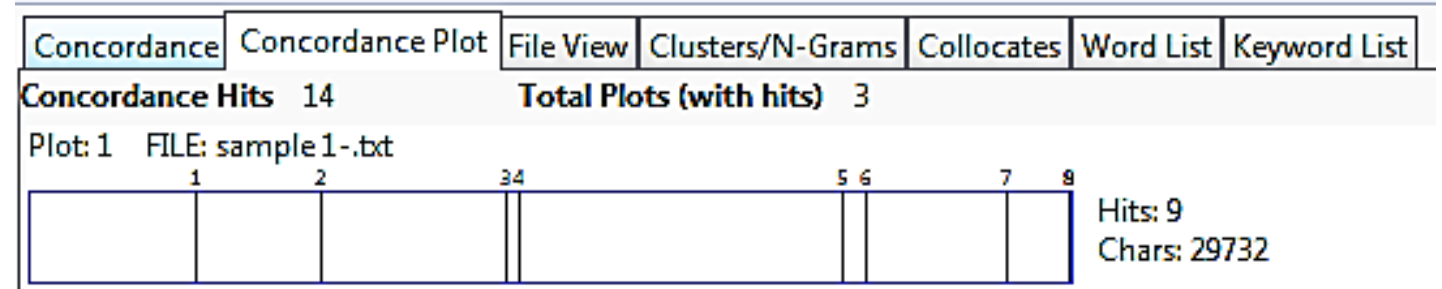

Plot: 2 FlLE: sample 2-.txt

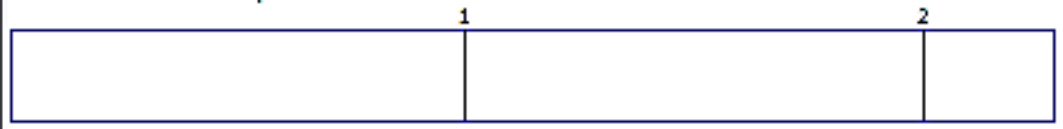

Hits: 2

Chars: 6985

Plot: 3 FlE: sample 3.txt

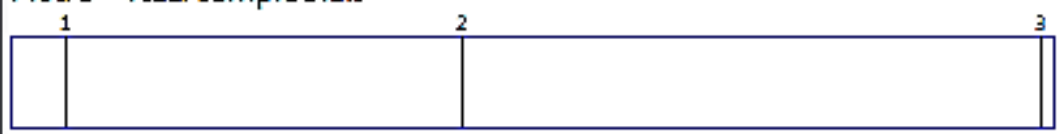

Hits: 3

Chars: 13194

Figure (5): Concordance plot no. 5 of we-need Structure

"We-have-to-structure" is the fifth linguistic structure which expresses the institutional aims of WHO. Table (6) illustrates that "wehave-to-structure" prevails in the three samples under analysis. Figure (6) clarifies that the highest prevalence of "we-have to structure" is in sample (1), followed by sample (3), then sample (2). 


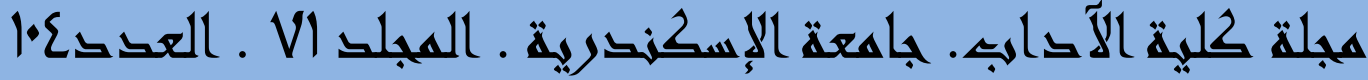

\begin{tabular}{|c|c|c|}
\hline \multicolumn{3}{|c|}{\begin{tabular}{|l|l|l|l|l|l|} 
Concordance & Concordance Plot & File View & Clusters/N-Grams & Collocates & Word List \\
Keyword List
\end{tabular}} \\
\hline \multicolumn{3}{|c|}{ Concordance Hits 6} \\
\hline $\mathrm{KW}$ & WIC & File \\
\hline 1 & is it spreading? At the time I said, we have to base our actions on imperfect evidence. & sample 1-.txt \\
\hline 2 & is based on all of the evidence that we have to date. The second question about mild & sample 2-txt \\
\hline me & nes that that is essentially the balance we have to find between the communications and $m$ & sample 1-txt \\
\hline 4 & no PHEIC, either green or red. I think we have to now revise that. It would be & sample 3.txt \\
\hline tha & hat means. So any political action $\backslash \times 85$ we have to see it in relation to the & sample 3.txt \\
\hline we & we balance those two things? Because we have to. This is coming to your question & sample 1-.txt \\
\hline
\end{tabular}

Table (6): we-have to structure

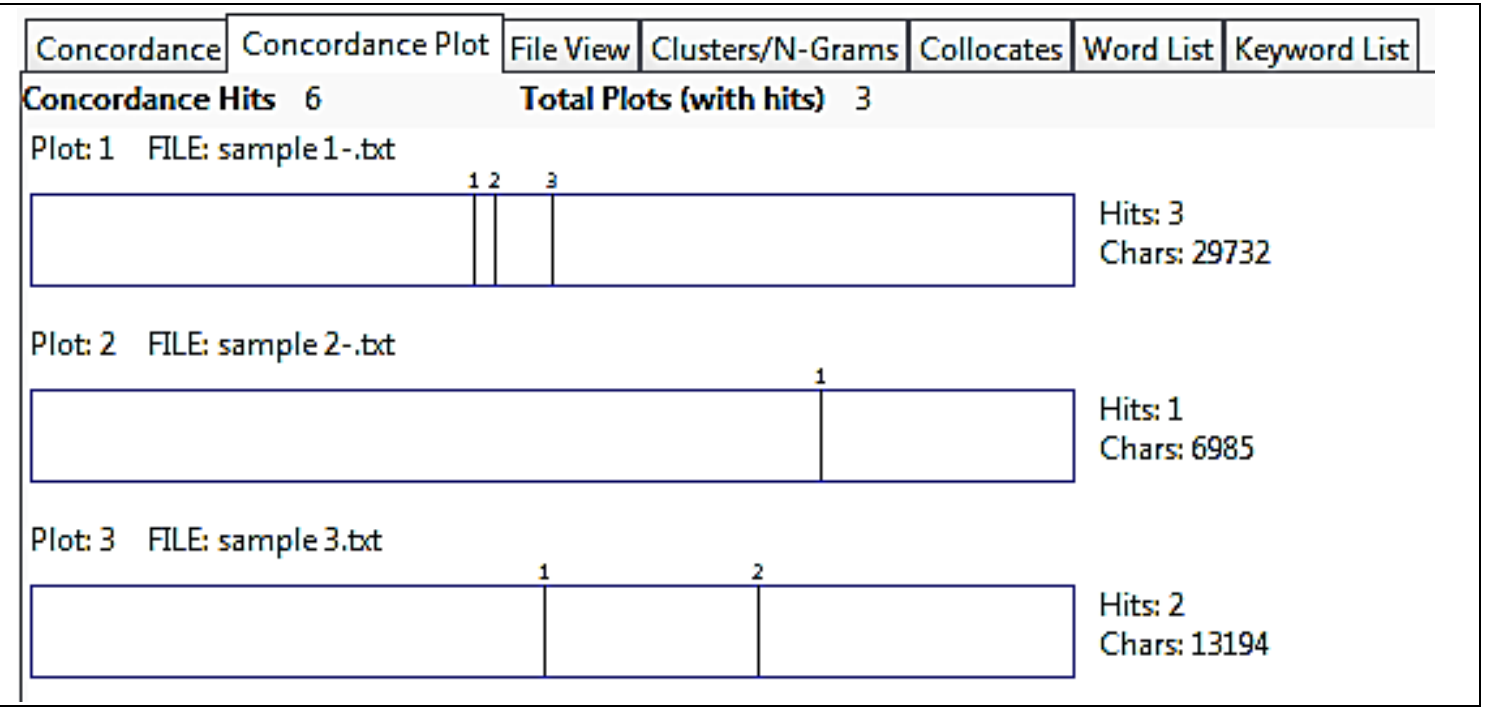

Figure (6): Concordance plot of we-have to structure

Likewise, the descriptive communicative purpose is achieved by the first person plural pronoun. The institutional addressors describe the current state of affairs in relation to Coronavirus. This is achieved by using "we-don't structure". Table (7) reveals that the "we-don't structure" is used by the institutional addressors to describe that they do not have full understanding of the virus transmissibility; they do not have a therapy; they do not have a vaccine; and they do not know what the amplifiers were in Wuhan. The "we-don't structure" has frequency of 11 times, nonetheless, it prevails only in samples (1) and (2) as figure (7) reveals. 


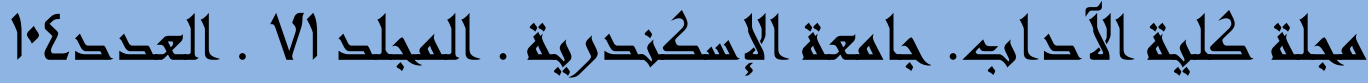

\begin{tabular}{|c|c|c|}
\hline \multicolumn{3}{|c|}{ 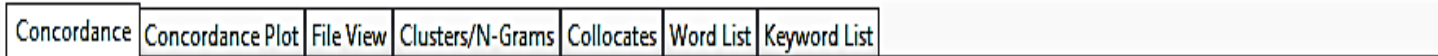 } \\
\hline \multicolumn{3}{|c|}{ Concordance Hits 11} \\
\hline & KWC & Flle \\
\hline 1 & and this is the issue at the moment. We do not fully understand either of those parameters & s sample 1-txt \\
\hline 2 & people be concerned? A new virus has emerged. We do not have a therapy. We do not & sample 1-.txt \\
\hline & has emerged. We do not have a therapy. We do not have a vaccine. That disease has & sample 1-tot \\
\hline & say, something must be done. Well, unfortunately we do not have the opportunity to say, something & sample 1-txt \\
\hline & provide front-line care for a disease that we do not have a treatment for or a & sample 1-txt \\
\hline & ommittee to consider tomorrow. Having said that, we do not know the originator [?] events here. We & sample 1-txt \\
\hline & , we do not know the originator [?] events here. We do not know that there were not multiple & sample 1-.txt \\
\hline & nts that occurred that are driving the infection. We do not know what the amplifiers were originally & sample 1-.txt \\
\hline & how many people were infected and right now we do not know that number, so it is & 2-tott \\
\hline & information to make a perfect decision, but if we do not make decisions and act, therefore we & samp \\
\hline & we do not make decisions and act, therefore we do not take any & sample 1-.txt \\
\hline
\end{tabular}

Table (7): we-do not structure

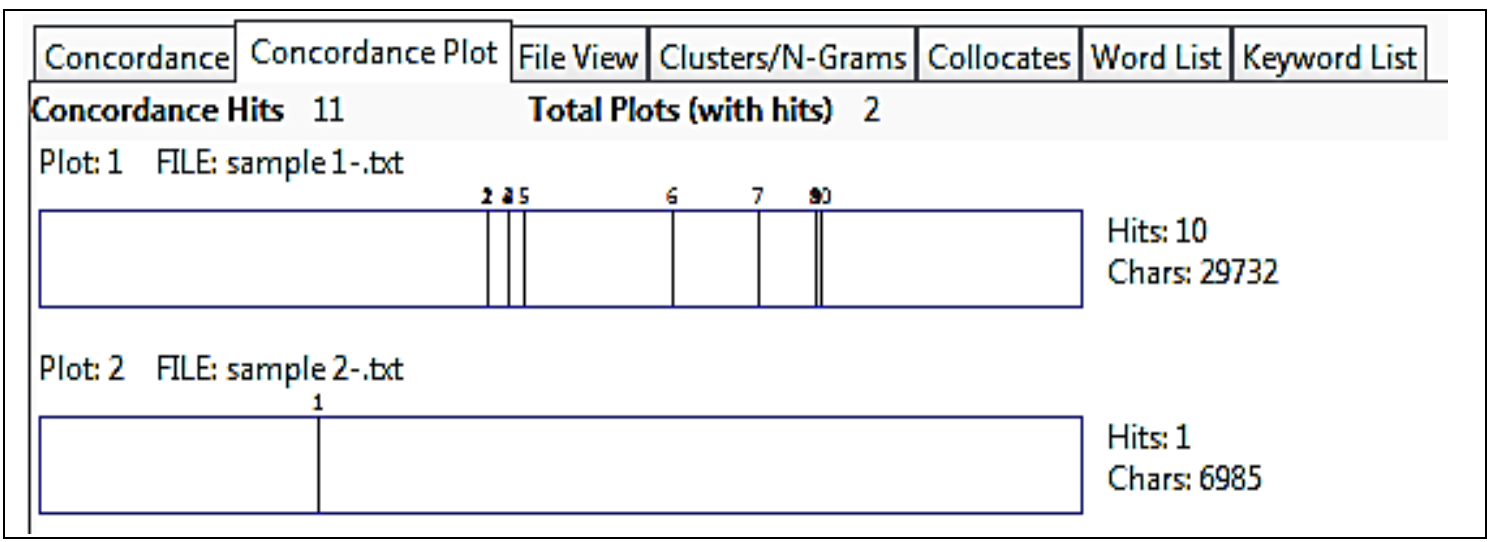

Figure (7): Concordance plot of we-do not structure

The other two structures used by the addressors to express the exerted institutional efforts by WHO are the "we-have-p.p. structure" and the "we-have-been structure". Table (8) reveals that the present perfect tense is used by the addressors to express exerted institutional efforts such as consulting the experts, asking member states of imported cases to share data, and bringing the best minds of scientists, clinicians, disease trackers and modelers. 
$\begin{array}{lll}\text { Concordance Hits } & 37 & \\ \text { Hit } \quad \text { KWIC } & \text { File }\end{array}$

top priority. With that in mind, we have a chance because when a sample 1-txt

In terms of the virus evolution, we have a global network of scientists sample 2-.txt we do have a chance. So we have a job to do in sample 1-.txt

to support China in doing that. We have a job to do in sample 1-.txt

tell you one of the strategies we have agreed with China. China really sample 3.txt

So we $x 92$ re considering that. We have already consulted some experts internat sample 3 .txt

ave four levels in this response. We have an intense response going on sample 1-.txt

$m$ that. Maria? Just in addition, we have asked all member states who sample 1-.txt

ation is the most powerful tool we have at our disposal right now sample 1-.txt

gional emergency director and we have been in touch with our sample 1-.txt

tingly, over the last three years, we have been working not only with sample 1-.txt

$k_{r}$ as the Director-General said, we have been working on a strategic sample 1-.txt

is taking action. On our side we have brought together some of the sample 1-.txt

partners and our concern is if we have cases in countries who have sample 3.txt

how many have been reported. We have engaged all countries that have sample 2-.txt

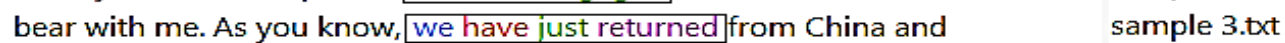
in other parts of China, but we have not heard of hospital outbreaks sample 2-.txt to come in. The fact that we have not seenlarge-scale health sample 1-.txt more to the Taiwanese experts we have. Number one, it is very sample 1-.txt

20 closely. The fact that to date we have only seen 68 cases outside China sample $3 . t x t$

21 have expertise on the call but we have people who have direct involvement

sample 2-.txt ometimes twice a day \} \times 9 6 \text { and we have received, in advance of the }

this outbreak evolves. Yes. So we have reports of a hospital cluster

in Wuhan and Hubei Province. We have responses going on in other

gh close contact. The source, as we have said before, is still unclear

on a daily basis to us. We have seen no obvious lack of

litional cases. Outside of China we have seen some example of human-

Taiwan, or Taipei Municipality. We have Taiwanese experts involved in all

terrupt chains of transmission. We have the 15 countries who have imported

sample 1-.txt

sample 2-.txt

sample 1-.txt

sample 1-.txt

sample 1-.txt

sample 2-.txt

sample 1-.txt

sample 1-.txt

e the global collaborations that we have through the WHO collaborating center

sample 1-.txt

spreading? At the time I said, we have to base our actions on

sample 1-.txt

on all of the evidence that we have to date. The second question

th that is essentially the balance we have to find between the communications

, either green or red. I think we have to now revise that. It

sample 2-.txt

sample 1-.txt

sample 3.txt

sample 3.txt

ans. So any political action $\backslash 855$ we have to see it in relation

sample 1-.txt

ance those two things? Because we have to. This is coming to

ic sample $3 . t x t$

Table (8): "we-have-p.p. structure" and the "we-have-been structure"

Table (9) clarifies the pronominal use in the data under analysis. It reveals that the most frequent pronominal use is the first person plural pronoun. The second frequent use is the second person pronoun with frequency of 80 times. Figures (8) and (9) reveal the prevalence of these pronouns respectively.

\begin{tabular}{|l|l|l|l|l|}
\hline Pronoun & Sample (1) & Sample (2) & Sample (3) & Sum \\
\hline we & 115 & 36 & 62 & 213 \\
\hline you & 46 & 6 & 28 & 80 \\
\hline
\end{tabular}

Table (9): pronominal use 


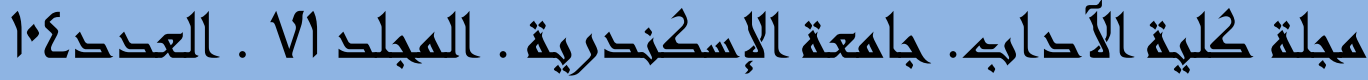

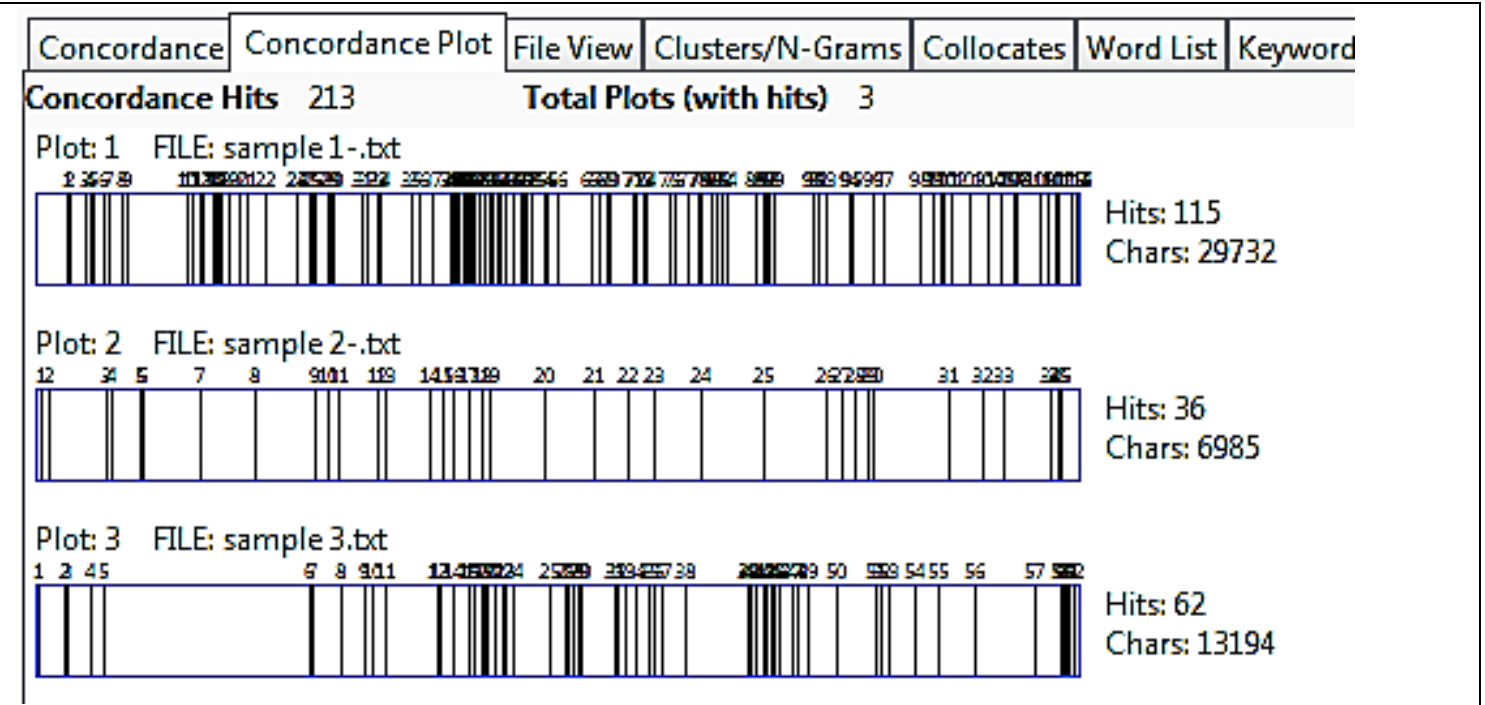

Figure (8): Concordance plot of first person pronoun use

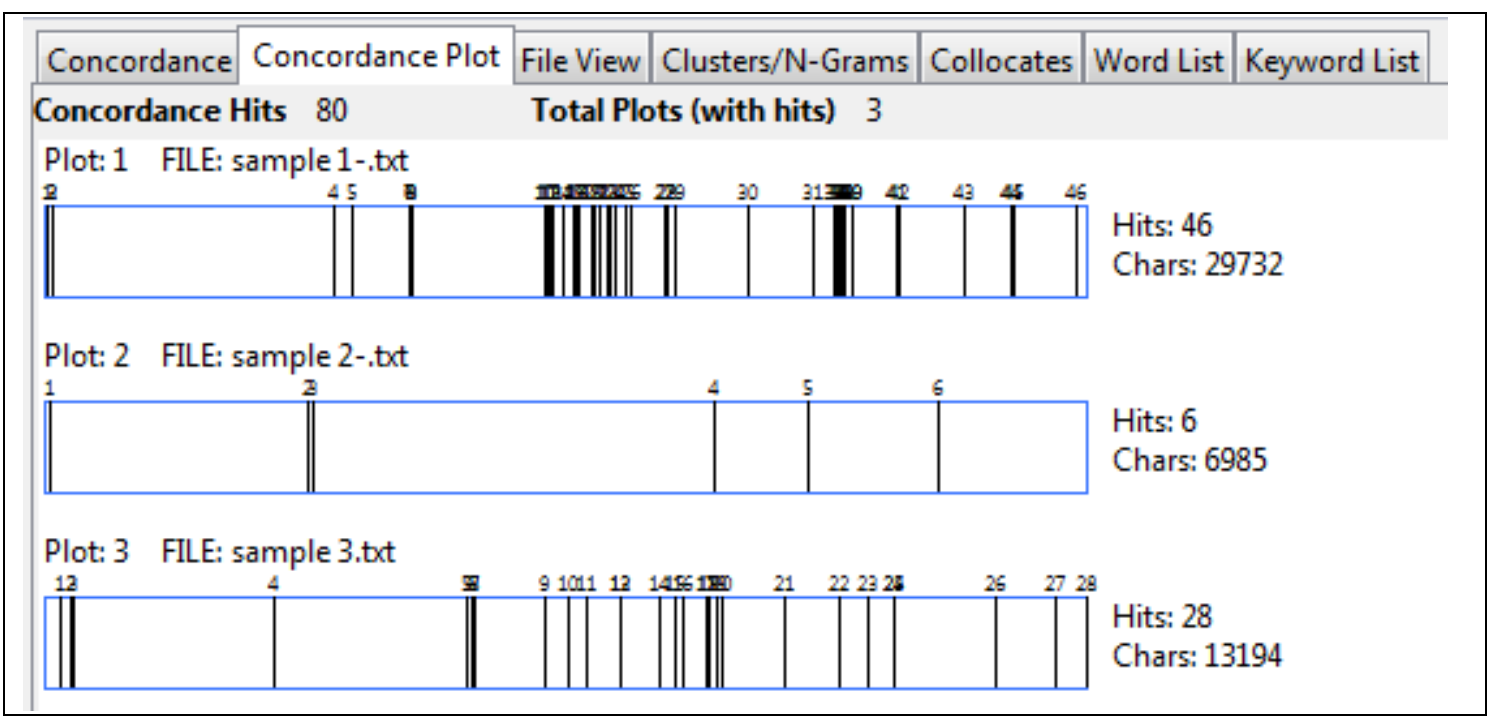

Figure (9): Concordance plot of second person pronoun use

The variant professional affiliation appears in the scientists' representation of WHO and the journalists' representation of different news agencies. Its influence appears in the allocation of turns, i.e., the right to speak. While the journalists have the right to ask and direct questions to the scientists in the conference, the scientists do not have the right to ask questions. Their duty is to respond to the journalists' questions. They are responses that represent their institution, i.e., the World Health Organization.

It should be pointed out that in the three samples under analysis when a scientist responses to a journalist's question, he implicitly directs his response to all the attending journalists and the conference online viewers. His CP is promotional of the WHO ideologies and international power. It is the promotional aim that the scientists are charged to perform 
in an institutional register about epidemics. This is clear in expressing the exerted efforts and future possible aims of WHO in controlling covid-19. The second aim of the publicly directed institutional scientific register is informative. The scientists inform the attendees about the novel corona virus, the precautions to prevent the virus transmission, and the current numbers of infected cases.

The interactiveness between the participants appears in two linguistic features. The first of which is the pronominal use of the second person pronoun with a frequency of 80 times used mainly to direct the contributions to the addressees. The second linguistic feature of interactiveness that is used elaborately and functionally by the journalists is the question form.

The $\mathrm{CP}$ of the journalists is mainly to request information about Covid-19. The journalists achieve the interrogative purpose by using the question pattern. In the three samples under analysis, the journalists use three different categories of questions: direct, indirect, and yes/ no questions. The direct questions have a frequency of 10 times as table (10) reveals:

What guarantees you've had from the government as to access?

What is it you think about this?

What percentage of the cases reported to WHO are asymptomatic

How much is that worrying you, given the recent case in Germany?

What more can we expect that will occur?

What does this tell to you?

How will this advance the operation in terms of trying to tackle this and contain this virus?

How many generations are there so far and

How is it going to affect the ongoing solution to contain the epidemic?

How long do you think it would take before the number of infected cases...

Table (10): journalists' use of direct-questions

The second category of questions is shown in structures such as "could you tell us...", "can you elaborate on...", "can you provide some clarity as to...", and "can you tell us a little but more about...". These structures are always followed by a wh-word. This category of indirect questions is used functionally by the journalists to achieve two functions: to appear more polite and to reflect a high level of formality. Polite and formal questions are distinctive linguistic features of the journalists' questions in 


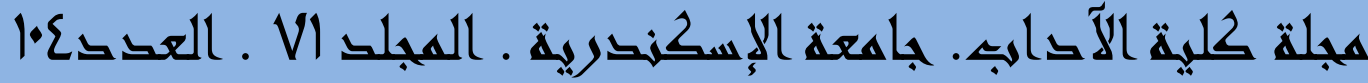

the institutional scientific register about epidemics. This category has a frequency of 7 times, as table (11) reveals.

\begin{tabular}{|l|l|}
\hline - & Could you tell us who they ... \\
\hline - & Can you elaborate more on what kind of data-sharing \\
\hline - & Can you provide some clarity as to why information about \\
\hline - & $\frac{\text { Can you tell us a little bit more about what sort of skills you're }}{\text { looking for }}$ \\
\hline - & $\frac{\text { Can you tell us a little bit more about what sort of skills you're }}{\text { looking for, }}$ \\
\hline - & I was wondering if you could say how good an idea you think it is \\
\hline that countries are evacuating their citizens ... \\
\hline
\end{tabular}

Table (11): journalists' use of polite formal questions

The third category is yes/no questions. The operator in this category is "verb to do" found in 8 times followed by "verb to be" used in 5 times and the least occurrence is attributed to a modal verb "would" which is used once, as table (12) reveals.

- Do you think the infection controls are adequate?

- Do you have any scientific explanation to this or

- Do you need more support from member states?

- Do you fear that politics and international politics

- Do you believe this has had an effect on China's ...

- Do you have plans to include US experts from CDC or other agencies in this mission ...

- Did you learn anything major from your trip in China?

- Doesn't that leave the possibility that there will be a blind spot...

- Are you receiving that data now?

- Are you afraid that this epidemic has a potential of being ...

- Are you already in talks with the World Bank, with other ...

- Are we making too much headlines about the coronavirus ...

- Is WHO ready to deal with this new big challenge?

- Would you say that you believe that China has been transparent about this

Table (12): yes/no questions

The journalists' questions are characterized by being preceded by declarative sentences. These declarative sentences have four different functions: to specify the addressee, as in "... two questions for Dr. Ryan", 
"My question is both for the Director-general and Dr. Ryan", and in "I have another question for Dr. Tedros". The second function is to specify the topic, for example "I just wanted to follow up on the transparency question". The third function, which seems similar to the second one, is to narrate relevant events to the question, for example "you've come back from China, sir, with this promise from the Chinese authorities of being able to send an international mission ....can you tell us a little bit more about what sort of skills you are looking for ?" Another example is in "you were a minster. You know very well, sir, that everything is political.... do you fear that politics and international politics ... limit your capacity to act?" The last function is self-introduction, as in "Nina Larson, AFP" where AFP stands for Agence France-Presse ; in "John Zarocostas for France 24"; and in "Hello Lisa Schlein, voice of America ..."

On the other side, the only use of question pattern by the scientists is the rhetorical use. For example, "Can we gather enough evidence...?"; "Can we use that evidence to drive a public health strategy ...?"; "Can we balance those two things?" The question pattern structure appears only in Sample (1) as a rhetorical device to formulate the intended aims of the WHO. Based on the context, the implied answer is "yes".

Other examples of rhetorical questions used only in Sample (1) are the following: "Why would not people be concerned"; "Can we find a way to make that happen?"; "How do we do that together?"; "How do we share national information?" "Can this be controlled?" and in "Which way is it spreading?" The only exception of a question pattern directed by a scientist to a journalist is in Sample (2) where the addressor requests clarification about the journalist's question in "Do you have a date and a time line where you are concerned about this in terms of dates?"

The unequal relation between the participants appears in the unimpeachable and unquestionable status of the scientists' contributions. This credibility stems from the scientific specialty of the scientists in health emergencies and emerging diseases; and their professional affiliation to the WHO which strengthens the credibility and reliability of their contributions.

The role of the general shared knowledge in understanding the context of situation appears in a number of instances. In Sample (1), the addressor says "this is our first opportunity to brief you on this". It is shared knowledge between the participants that the first use of the demonstrative "this" refers to the current conference while the second use 
refers to the visit to China. Similarly in "He will reconvene the international Health Regulations Emergency Committee", the participants share the knowledge that the emergency committee is a department that is specialized in regulations of emergent diseases in WHO.

Likewise, in describing the response to coronavirus in "we clearly have four levels in this response" and in "we're sharing information, guidelines, and tools in real time on our website", the participants share the general knowledge that the intended response and the intended information are about coronavirus. Although not mentioned literally, it is general shared knowledge between the participants that the conference is about the novel coronavirus outbreak in China.

The role of specialized knowledge appears in the numerous abbreviations and acronyms used by the scientists and understood by the journalists. For example, in Sample (2), the abbreviation "sitrep" stands for "situation reports" (Sitrep, Segen's Medical Dictionary, 2011). In Sample (3), the acronym "PBAC" stands for "Pharmaceutical Benefits Advisory Committee" (Jablonski, 2016, p. 325).

Likewise in Sample (2), the acronym "MERS" stands for "Middle East Respiratory syndrome" (Jablonski, 2016, p. 265). In Sample (3), the addressor says "the IHR now is PHERC or no PHEIC either green or red" where the "IHR" stands for "International Health Regulations" (Jablonski, 2016, p 213), and the "PHEIC" stands for "Public Health Emergencies of International Concern" (PHEIC, TheFreeDictionary.com, 2020). The acronym "SARS" stands for Server Acute Respiratory Syndrome (Jablonski, 2016, p. 384); CFR stands for "Case Fatality Ration" (Jablonski, 76); and GOARN stands for "Global Outbreak Alert and Response Network" (Jablonski, 2016, p. 176). Finally, DG stands for director-general and the most used abbreviation in the three samples under analysis is WHO stands for the World Health Organization (Jablonski, 2016, p. 458).

Likewise, the role of specific knowledge in interpreting the register under investigation appears in the scientific terminology. For example, "genome" refers to "the entirety of the genetic information encoded by the nucleotide sequence of an organism, cell, organelle, or virus" (Dorland, 2012, p. 771). "Cluster" refers to "a group of similar objects, events, or other elements in close proximity" (Dorland, 2012, p. 375). "Epidemiology" refers to "the science concerned with the study of the factors determining and influencing the frequency and distribution of disease, injury, and other health-related events" (Dorland, 2012, p. 631). 
"Infection" refers to "the invasion and multiplication of microorganisms or parasites in body tissues" (Dorland, 2012, p. 935). "Vaccine" means "a suspension of attenuated or killed microorganisms or of antigenic proteins derived from them, administered for the prevention, amelioration, or treatment of infectious diseases"(Dorland, 2012, p. 2015). Diagnosis denotes " the determination of the nature of a case of disease... distinguishing one disease from another"(Dorland, 2012, p. 507).

The spoken mode of the three samples under analysis influence the production circumstances of the participants. While the journalists have time to prepare their questions to some degree, the scientists do not have foreknowledge of these questions and accordingly do not have time to edit their responses. This is clear in the ungrammatical and incomplete sentences used by the scientists. In Sample (1), the predicate of "China and Chinese scientists" is missing in "Remember in this that China and Chinese scientists ... it probably was the most rapid characterization". Likewise, the infinitive after the particle "to" is missing in "In a crisis it's very easy to... sometimes I've called it the something must be done club". Likewise, incomplete sentences are used in sample (2) where the predicate of "rapid sharing" is missing in "yes just to complement what Mike has said, the rapid sharing...when we say rapid, we mean days". Similarly, the complement after verb to be is missing in "yes, what I can add to that is ... what we can say to date is how many".

The time and place of the register under analysis are shared by the participants except for a portion of online journalists as the conference coordinator mentions in "... would like to say to journalists who are watching us that they ask their questions using the hashtag \# ask WHO". Sharing the same physical context of time and place between the participants appears in the use of situation-dependent reference. For example, the adverbial "yesterday" is a context-dependent reference that refers to "on the day preceding today" (Meriam Webster online dictionary, n. d.), i.e., one day before the conference date. This is clear in the following examples:

- "Thank you, so we mentioned yesterday in our sitrep" and in "I had direct discussions with the DG and ministers in China on that yesterday" (Sample (1)).

- "As you know, we have just returned from China and yesterday we had the opportunity to meet with President Xi Jinping" and in "... the cases in Germany reported yesterday originated with a Chinese woman " (Sample (3)). 


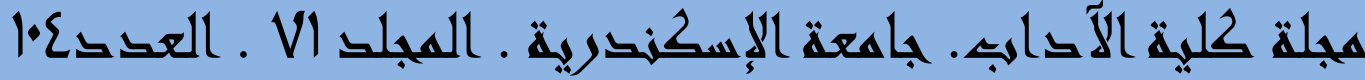

Another situation-dependent reference of place appears in the adverb "here" which refers to the current place of the conference. This is clear in "Maria Van Kerkhove, who's with me here, can give more detail on that" and in "I have said to you of the core press crops here" in Sample (1). Similarly, situation-dependent reference of place appears in "the strategy we followed here is serious" (Sample (3)).

The vocabulary in the three samples under analysis is used functionally to communicate the CPs of the scientists. The first CP in the press conference is a description of the visit to China and the Chinese government response to coronavirus. This is achieved by the addressor's functional use of the noun "China" in 78 times, as the Word List tool reveals in figure (10):

\begin{tabular}{|c|c|c|c|c|c|}
\hline \multicolumn{4}{|c|}{ AntConc 3.5.8 (Windows) 2019} & \begin{tabular}{|l|l|l|}
$口$ & 回 \\
\end{tabular} & $\mathbb{E}$ \\
\hline \multicolumn{6}{|c|}{ File Global Settings Tool Preferences Help } \\
\hline \multirow{3}{*}{$\begin{array}{l}\text { Corpus Files } \\
\begin{array}{l}\text { sample 1-txt } \\
\text { sample 2-txt } \\
\text { sample 3.txt }\end{array}\end{array}$} & Concordanc & \begin{tabular}{|l|l|l|} 
Concordance Plot & File View & Clust \\
\end{tabular} & Grams Collocates Word List Keyword List & & \\
\hline & $\begin{array}{l}\text { Word Types: } \\
\text { Rank Frea }\end{array}$ & $\begin{array}{l}1444 \text { Word Tokens: } 8700 \\
\text { Word }\end{array}$ & $\begin{array}{l}\text { Search Hits: } 0 \\
\text { Lemma Word Form(s) }\end{array}$ & &. \\
\hline & \begin{tabular}{|l|l}
16 & 78
\end{tabular} & china & & & 国 \\
\hline
\end{tabular}

Figure (10): word list of first person pronominal use

Table (13) clarifies that the proper noun "China" occurs most frequently in the prepositional phrase structure: "in China" with a frequency of 17 times; "of China" with a frequency of 7 times; "outside China" with a frequency of 7 times; and "to china" with a frequency of 8 times. This is attributed to the functional use of the proper noun "China", i.e., the epicenter of coronavirus pandemic. The prepositional phrase "in China" is used as a post modifier of nouns such as "people", "workers", "government", "partners", "outbreaks", and "office". 
the health of people in China ahead of anything ront-line health workers in China and many from

king with the government in China and other governments are many GOARN partners in China including the China the DG and ministers in China on that yesterday.

rd of hospital outbreaks in China other than the caused a major epidemic in China. That is a

touch with our office in China this afternoon to sponse is fully underway in China. This team is a job to do in China to support China

DG said, our colleagues in China were very keen that action, especially in China. What we know on in other provinces in China where transmission is , it was the lab in China who contacted Germany s clearly still centered in China with the overwhelming

nfections in other parts of China, but we have then and the behavior of China now. Countries are son between the behavior of China then and the

hat has occurred outside of China. These developments in other countries outside of China. This is something nation of the government of China to put the ditional cases. Outside of China we have seen outbreak, all of them in China. Our thoughts are

d cases, including 5,997 in China, representing almost 99\%

sample 1-.txt sample 1-.txt sample 1-.txt sample 1-.txt sample 1-.txt sample 2-.txt sample 3.txt sample 3.txt sample 1-.txt sample 1-.txt sample 1-.txt sample 1-.txt sample 1-.txt sample 1-.txt sample 1-.txt sample 1-.txt sample 1-.txt

sample 2-.txt sample 1-.txt sample 1-.txt sample 1-.txt sample 2-.txt sample 1-.txt sample 2-.txt

have only seen 68 cases outside China and no deaths an-to-human transmission outside China are of course rning. Also, the numbers outside China are still relatively

.I gave you figures. 68 outside China, 68 cases in 15 coun vast majority of cases outside China have a travel an-to-human transmission outside China in three countries,

with their families, but outside China there are only 68

sample 3.txt sample 3.txt sample 3.txt sample 3.txt sample 3.txt sample 3.txt sample 3.txt

sample 3.txt sample 1-.txt sample 1-.txt sample 1-.txt sample 3.txt sample 3.txt sample 3.txt sample 1-.txt

taking her return flight to China. After her return e associated with travel to China and, of those, team that will go to China and there are ernational experts to go to China and work with have a travel history to China or contact with China. After her return to China, she was tested with a travel history to China. There are signs ssible. During our trip to China we were very

Table (13): prepositional phrase structure including proper noun "China"

Table (14) shows that the adjective "Chinese" is another recurrent lexeme used to achieve the descriptive $\mathrm{CP}$ of the visit to China and the Chinese response to the coronavirus pandemic. It is used as a premodifier to describe nouns such as "authorities", "colleagues", "experts", "perspective', and "government". Moreover, it collocates with "experts" in 4 times, "authorities" in 4 times, and "government" in 2 times. 


\begin{tabular}{|c|c|c|}
\hline \multicolumn{3}{|c|}{\begin{tabular}{|l|l|l|l|l|l|l|} 
Concordance & Concordance Plot & File View & Clusters/N-Grams & Collocates & Word List & Keyword List \\
\cline { 2 - 3 }
\end{tabular}} \\
\hline \multicolumn{3}{|c|}{ Concordance Hits 17} \\
\hline Hit & KWIC & File \\
\hline || 1 & urther collaboration with Chinese authorities and having teams & sample 1-.txt \\
\hline $\mid 2$ & prior to her departure. Chinese authorities immediately notif & sample 3.txt \\
\hline 3 & regards to transmission, Chinese authorities told us during & sample 2-.txt \\
\hline 4 & pidemiologic report from Chinese authorities $\backslash$ x96 in fact, & sample 1-.txt \\
\hline | 5 & are already working with Chinese colleagues and I had & sample 1-.txt \\
\hline || 6 & aspects of this. So Chinese expertise and scientific know & sample 1-.txt \\
\hline || 7 & I might add that Chinese experts are involved in & sample 1-.txt \\
\hline 8 & China and work with Chinese experts to better understand & sample 1-.txt \\
\hline $\mid$ & vork in collaboration with Chinese experts to come to & sample 1-.txt \\
\hline 10 & , and to work with Chinese experts to learn as & sample 1 -.txt \\
\hline 11 & $e_{r}$ and professionalism of Chinese front-line health workers. & sample 1-.txt \\
\hline 12 & of engagement of the Chin & sample 1-.txt \\
\hline 13 & been massive and the Chinese government deserves huge $\mathrm{cr}$ & sample 1-.txt \\
\hline 14 & analysis to what the Chinese have done. They have & sample 1-.txt \\
\hline 15 & to that from the Chinese perspective. We are already & sample 1 -.txt \\
\hline 16 & this that China and Chinese scientists $\backslash \times 85$ it probably & sample 1-.txt \\
\hline 17 & sterday originated with a Chinese woman who travelled from & sample 3.txt \\
\hline
\end{tabular}

Table (14): frequency of "Chinese"

Likewise, table (15) displays the proper noun "Wuhan" with a frequency of 17 times. It occurs most frequently in the prepositional phrase "in Wuhan" which is used as a post modifier of nouns such as "clinicians", "measures", and "authorities".

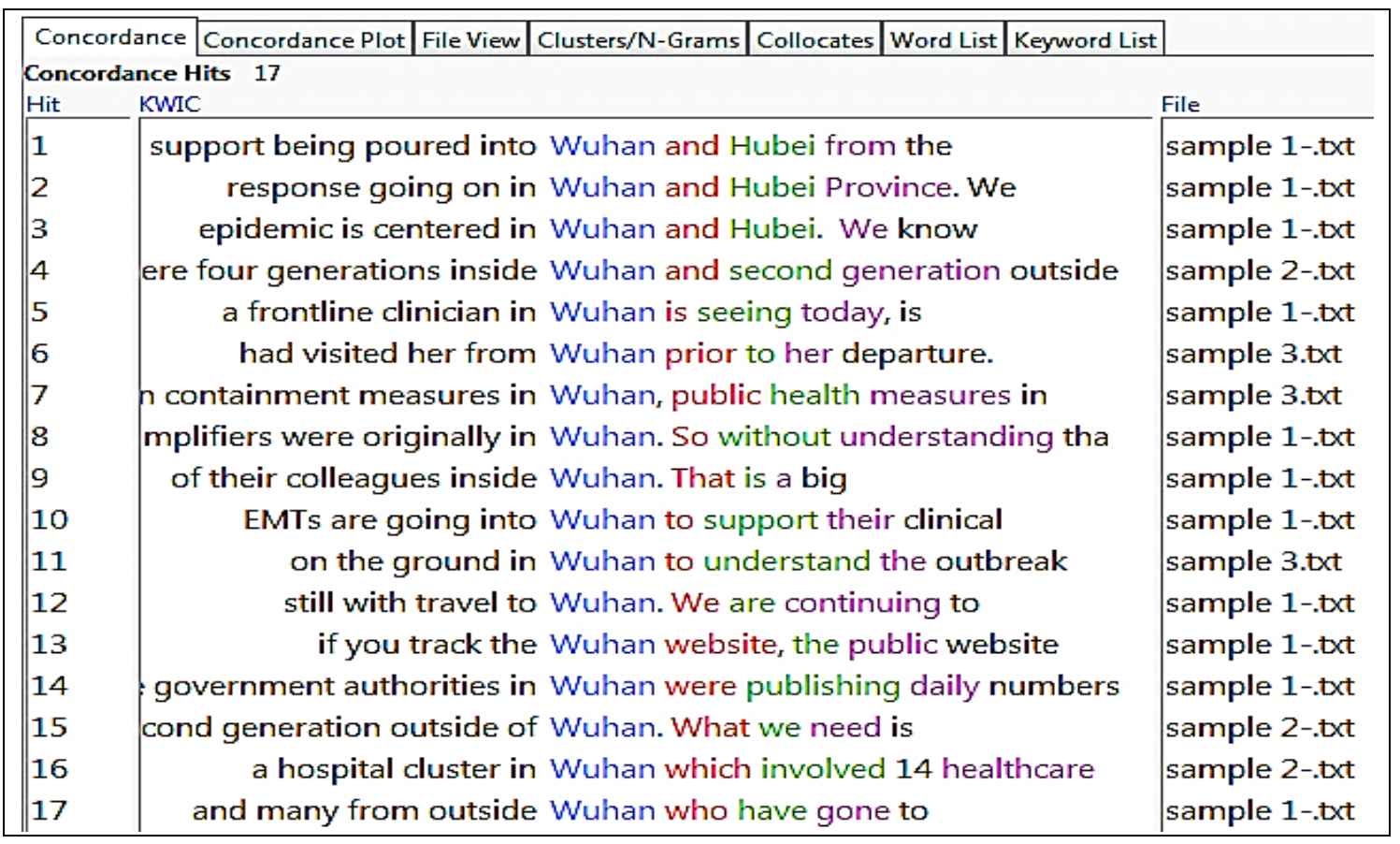

Table (15): frequency of "Wuhan" 
The description of the Chinese government's response to coronavirus is communicated by using lexemes such as "response" with a frequency of 22 times, as table (16) manifests:

\begin{tabular}{|c|c|c|}
\hline \multicolumn{3}{|c|}{ Concordance Hits 22} \\
\hline Hit & KWIC & File \\
\hline 1 & least funded of all the Ebola response activities was the preparedness in the & sample 1-.txt \\
\hline 2 & ht deserves huge credit for that response and for the transparency in which & sample 1-.txt \\
\hline 3 & preparedness is worth a ton of response and I have said to you, & sample 1-.txt \\
\hline 4 & China working directly on the response and that frontline experience ${ }_{r}$ understa & sample 1-.txt \\
\hline 5 & id commitment of an epidemic response at this level in terms of & sample 1-.txt \\
\hline 6 & and the outbreak and direct the response. China $\times 92 \mathrm{~s}$ efforts to contain & sample $3 . t x t$ \\
\hline 7 & of the outbreak to guide global response efforts. In total, as you know ${ }_{t}$ & sample $3 . t x t$ \\
\hline 8 & s response. We have an intense response going on in Wuhan and Hubei & sample 1-.txt \\
\hline 9 & . The challenge is great, but the response has been massive and the Chinese & sample 1-.txt \\
\hline 10 & pulation since very early in this response. In fact, I think it is & sample 1-.txt \\
\hline 11 & an initiation of a response. The response is fully underway in China. This & sample 1-.txt \\
\hline 12 & e less, but nonetheless a major response is underway to track cases and & sample 1-.txt \\
\hline 13 & rther enhance the international response? It is not before nothing is & sample 1-.txt \\
\hline 14 & m the Global Outbreak Alert \& Response Network, from the Emergency Medical Tec & sample 1-.txt \\
\hline 15 & in the Global Outbreak Alert \& Response Network, many of whom were mobilizing & sample 1-.txt \\
\hline 16 & ve been working on a strategic response plan with the World Bank and & sample 1-.txt \\
\hline 17 & point to you from the Ebola response that the surrounding countries in terms & sample 1-.txt \\
\hline 18 & as not an initiation of a response. The response is fully underway in & sample 1-.txt \\
\hline 19 & his personal involvement in the response. This was for me a very & sample $3 . t x t$ \\
\hline 20 & with Minister Ma to discuss the response to the outbreak and how WHO & sample $3 . t x t$ \\
\hline 21 & nated and measured fashion in response to this evolving event. Thank you. & sample 1-.txt \\
\hline 22 & clearly have four levels in this response. We have an intense response going & sample 1-.txt \\
\hline
\end{tabular}

Table (16): frequency of "response"

Based on table (16), the lexeme "response" is pre-modified in "Chinese response", "intense response", "epidemic response", and in "major response". Moreover, it is used to express WHO efforts in the prevention of Ebola epidemic in Congo, and in the designation of "Global outbreak Alert \& Response Network" which reiterates in 14 and 15.

The international cooperation to share data about the novel coronavirus is the second important $\mathrm{CP}$ in the three samples under analysis. This is achieved by using lexemes such as "coronavirus" with a frequency of 9 times, as table (17) reveals. It collocates with the premodifier "novel" in 3 times $(2,4$, and 6$)$, and as a post-modifier in the prepositional phrase "of coronavirus" to post-modify lexemes such as "context", "spread", and "outbreaks" in 7, 8, and 9. 


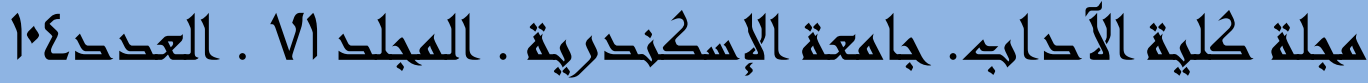

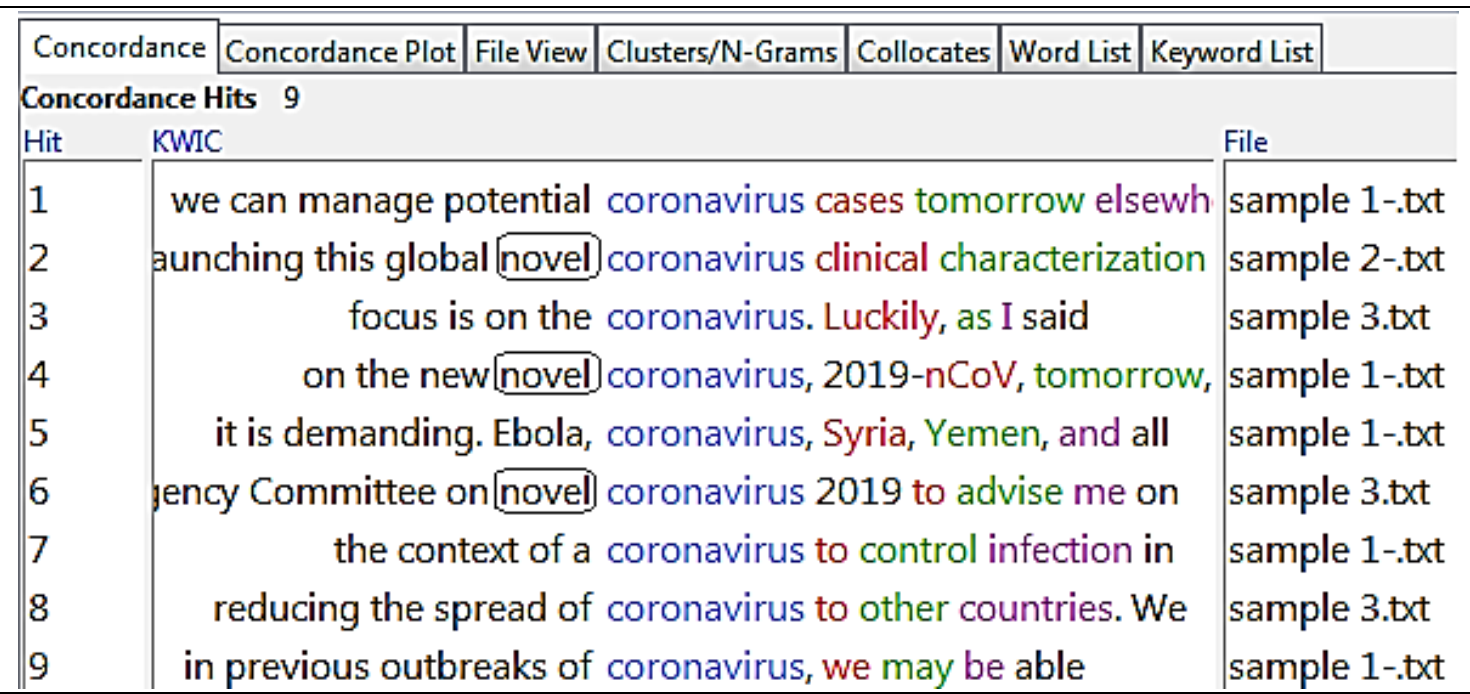

Table (17): frequency of "coronavirus"

Table (18) indicates that the lexeme "virus" is used alternatively with the lexeme "coronavirus" in the form of definite reference, i.e., "the virus" which has 21 times. As the conference aims to share information about the virus and stop its spread and transmissibility, the lexeme "virus" collocates with the gerund "sharing" in 3 times $(22,27,31)$; with the infinitive "to stop" in 3 times $(19,24,29)$; and with the lexeme "transmissibility" twice in (4, and 5). Moreover, the lexeme "virus" collocates with "spread" twice in (9 and 14), and with the lexeme "isolated" in 3 times $(1,20$, and 28). The prepositional phrase "of the virus" is used twice to post-modify "spread", "virulence", and "progress". 


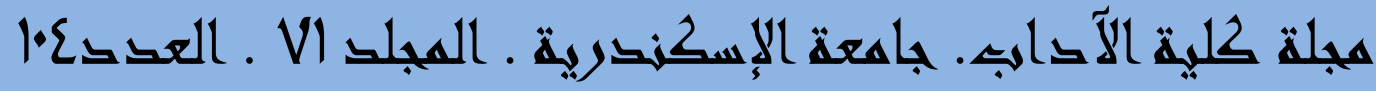

\begin{tabular}{|c|c|c|}
\hline \multirow{2}{*}{\multicolumn{2}{|c|}{ Concordance Hits 34}} & \multirow[b]{2}{*}{ File } \\
\hline & & \\
\hline 1 & . China has isolated that virus and China is not & sample 1-.txt \\
\hline 2 & the spread of this virus and control it as & sample $3 . t x t$ \\
\hline 3 & clinical severity of this virus, and other characteristics $s$ & sample 2-.txt \\
\hline 4 & and [transmissibility of the virus, and sharing data and & sample 3.txt \\
\hline 5 & the transmissibility] of the virus and the severity that & sample 1-.txt \\
\hline 6 & one first on the virus and then the more & sample 1-.txt \\
\hline 7 & and virulence of the virus and we $x 92 \mathrm{re}$ & sample 3.txt \\
\hline 8 & sequence of a novel virus available to the public & sample 2-.txt \\
\hline 9 & outward spread of the virus because you can manage & sample $3 . \mathrm{txt}$ \\
\hline 10 & learn more about the virus, but in doing that & sample 1-.txt \\
\hline 11 & better understand where this virus came from and why & sample 2-.txt \\
\hline 12 & outcome. A relatively mild virus can cause a lot & sample 1-.txt \\
\hline 13 & when you have the virus. China has isolated that & sample 1-.txt \\
\hline 14 & further spread of the virus. China identified the pathc & sample $3 . t x t$ \\
\hline 15 & Ix92 progress of the virus, especially in some countri & i sample $3 . t x t$ \\
\hline 16 & . In terms of the virus evolution, we have a & sample 2-.txt \\
\hline 17 & volution, but essentially the virus has been remarkably stabl & sample 1-.txt \\
\hline 18 & be concerned? A new virus has emerged. We do & sample 1-.txt \\
\hline 19 & use to stop the virus. If you do not & sample 1-.txt \\
\hline 20 & that has isolated]the virus in Australia. There are & sample 1-.txt \\
\hline 21 & direct involvement with the virus in the lab so & sample 2-.txt \\
\hline 22 & advance in sharing the virus is that the virus & sample 1-.txt \\
\hline 23 & to that collaboration around virus isolation and sharing. Wi & sample 1-.txt \\
\hline 24 & opportunity to stop this virus. It may evolve and & sample 1-.txt \\
\hline 25 & virus is that the virus itself allows you to & sample 1-.txt \\
\hline 26 & is when you have virus on an inanimate surface & sample 2-.txt \\
\hline 27 & the extra advantages that virus sharing gives you over & sample 1-.txt \\
\hline 28 & , with regards to the virus sharing, it is essential & sample 2-.txt \\
\hline 29 & designed to stopthe virus. So we need to & sample 1-.txt \\
\hline 30 & ssion characteristics of this virus, the clinical severity of & sample 2-.txt \\
\hline 31 & it can share the virus. There is no obstacle & sample 1-.txt \\
\hline 32 & being infected with this virus. Yes. Just to complement & sample 2-.txt \\
\hline 33 & you to grow the virus. You are able to & sample 1-.txt \\
\hline 34 & vitro drugs against the virus. You are able to & sample 1-.txt \\
\hline
\end{tabular}

Table (18): frequency of "virus" 
The lexeme "cooperation" reiterates in 4 times. It prevails in Samples (1) and (3). It is noted that the lexeme "cooperation" collocates with the lexeme "solidarity" only in Sample (3). It is a reference to "Solidarity and Cooperation" which is article number 13 of UNESCO's Universal Declaration on Bioethics and Human Rights as Garrafa (2014, 169) mentions in his essay "Solidarity and Cooperation".

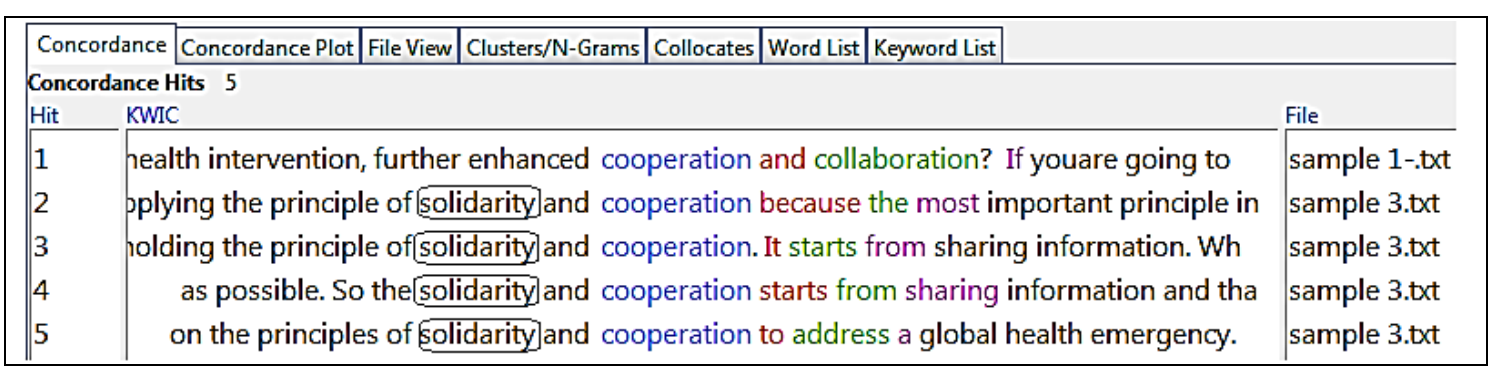

Table (19): frequency of "cooperation"

Table (20) reveals that the verb "share" is repeated 8 times. It collocates with "information" in (2 and 3), and with "data" in (1 and 4).

\begin{tabular}{|c|c|c|}
\hline \multicolumn{3}{|c|}{ 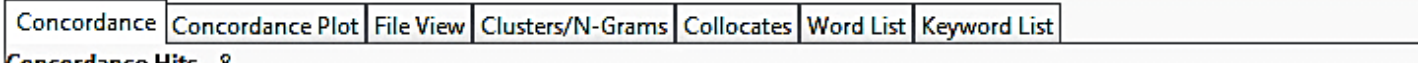 } \\
\hline \multicolumn{3}{|c|}{ Concordance Hits 8} \\
\hline $\mathrm{Hi}$ & KWIC & File \\
\hline $\mid 1$ & done. They have undertaken to share a similar disaggregated database with u & sample 1-.txt \\
\hline | 2 & to really make sure, to really share information in real time. That will & sample 3.txt \\
\hline | 3 & do that together? How do we share rational information on the risk, ratio & sample 1-.txt \\
\hline || 4 & for their own purposes but to share that surveillance data with us so & sample 1-.txt \\
\hline | 5 & every moment of every day. We share the concern of many people who & sample 3.txt \\
\hline 6 & partners to see how it can share the virus. There is no obstacle & sample 1-.txt \\
\hline || 7 & that we need member states to share with us and we would like & sample 1-.txt \\
\hline 8 8 & mber states who import cases to share with us on a daily basis & sample 1-.txt \\
\hline
\end{tabular}

Table 20: frequency of "share"

In table (21), the Gerund "sharing" has 16 times. It collocates with the noun "information" in 6 times $(4,5,6,7,14$, and 11), and as a compound noun in (3 and 9). 


\begin{tabular}{|c|c|c|}
\hline \multicolumn{3}{|c|}{ 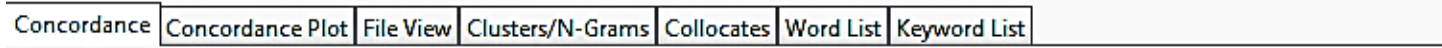 } \\
\hline \multicolumn{3}{|c|}{ Concordance Hits 16} \\
\hline Hit & WIC & File \\
\hline 1 & and transmissibility of the virus, and sharing data and biological material. I was & sample 3.txt \\
\hline 2 & there are genuine sensitivities around sharing data around new diseases and I & sample 1-.txt \\
\hline 3 & erstand the extra advantages that virus-sharing gives you over sequence-sharing. It & sample 1-.txt \\
\hline 4 & ge ones. Theyare always sensitive about sharing information about new diseases. In fa & sample 1-.txt \\
\hline 5 & solidarity and cooperation starts from sharing information and that $\times 92 \mathrm{~s}$ what & sample 3.txt \\
\hline 6 & enters that become established. We are sharing information, guidelines, and tools in $r$ & sample 1-.txt \\
\hline 7 & idarity and cooperation. It starts from sharing information. When a case crosses to & sample 3.txt \\
\hline 8 & dentifying the pathogen in record time, sharing it immediately, and sharing line list & sample 3.txt \\
\hline 9 & say, with regards to the virus-sharing, it is essential that viruses are & sample 2-.txt \\
\hline 10 & virus-sharing gives you over sequence-sharing. It would be good if you & sample 1-.txt \\
\hline 11 & ecord time ${ }_{s}$ sharing it immediately ${ }_{r}$ and sharing line list information, but not only & sample 3.txt \\
\hline 12 & pass to Maria on the data-sharing platform. There is much data that & sample 1-.txt \\
\hline 13 & . The difference and the advance in sharing the virus is that the virus & sample 1-.txt \\
\hline 14 & with patients so that they are sharing their information, who have direct ins & sample 2-.txt \\
\hline 15 & ollaboration around virus isolation and sharing. With regard to what we learnt & sample 1-.txt \\
\hline 16 & what Mike has said, the rapid sharing $x 85$ when we say rapid, we & sample 2-.txt \\
\hline
\end{tabular}

Table (21): frequency of "sharing"

"Studies", "data", "information", "collaboration", "network(s)", "scientists", "team", "media", "and colleagues" are recurrent lexemes that are used functionally to convey the second CP. The lexeme "studies" is repeated 5 times. It collocates with the pre-modifier "specific" in (1 and 4). It is pre-modified by the noun "transmission" in (2), and with clinical in (5), as table (22) reveals.

\begin{tabular}{|c|c|c|}
\hline \multirow{2}{*}{\multicolumn{3}{|c|}{$\begin{array}{l}\text { Concordance } \\
\text { Concordance Plot } \\
\text { Concordance View }\end{array}$}} \\
\hline & & \\
\hline Hitt & & Fille \\
\hline $\mid 1$ & especific pidemiologic-type studies, clinical studies that need & sample 2-.txt \\
\hline 2 & , how to manage transmission studies, how to manage clinical & sample 1-.tut \\
\hline 3 & provinces $s_{s}$ conducting further studies on the severity and & sample 3.txt \\
\hline 4 & uires very specifichousehold studies, only a few of & sample 1-.tut \\
\hline 5 & ologic-type studies, clinical studies that need to take & sample 2-.txt \\
\hline
\end{tabular}

Table (22): frequency of "studies"

Table (23) clarifies that the lexeme "data" collocates with the past participle adjective "disaggregated" in (7 and 12), and the present participle adjective "sharing" in (1,3, and 10). It is pre-modified in "new data" in (2); "standardized data" in (5); "reported data" in (9); and "surveillance data" in (13). 


\begin{tabular}{|c|c|c|}
\hline \multicolumn{3}{|c|}{ 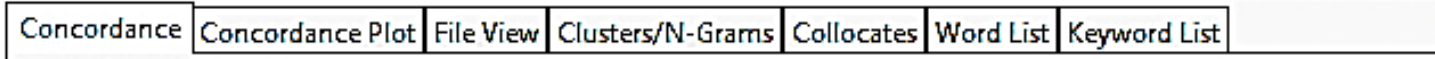 } \\
\hline \multicolumn{3}{|c|}{ Concordance Hits 14} \\
\hline Hit & KWC & File \\
\hline 1 & the virus $s_{s}$ and sharing data and biological material. I & sample 3.tut \\
\hline || 2 & all sorts of new data and we did not & sample 1-.txt \\
\hline 3 & sensitivities around sharing data around new diseases and & sample 1-.txt \\
\hline 4 & not only to collect data for their own purposes & sample 1-.txt \\
\hline 5 & daily basis a standardized data format for cases, for & sample 1-.txt \\
\hline 6 & like to have that data in the most organized & sample 1-.txt \\
\hline 7 & 92s data of disaggregated data. It is very important & sample 1-.txt \\
\hline 8 & full week $\backslash \times 92 \mathrm{~s}$ data of disaggregated data. It & sample 1-.txt \\
\hline 9 & out from routinely reported data on an epidemic the & sample 1-.txt \\
\hline 10 & to Maria on the datasharing platform. There is & sample 1-.txt \\
\hline 11 & platform. There is much data that we need member & sample 1-.txt \\
\hline 12 & $\mathrm{~h}$ aggregate and disaggregated data ${ }_{s}$ which will allow us & sample 1-.txt \\
\hline 13 & to share that surveillance data with us so we & sample 1-.txt \\
\hline 14 & through some of the data with you but it & sample 1-.txt \\
\hline
\end{tabular}

Table (23): frequency of data

Based on table (24), the lexeme "information" recurs 16 times. Using the Collocates Tool in Antconic Software, it collocates with "sharing" in 6 times, in $(1,2,6,7,15$, and 16), and the pre-modifier "rational" twice, in (10, and 12).

\begin{tabular}{|c|c|c|}
\hline \multicolumn{3}{|c|}{ 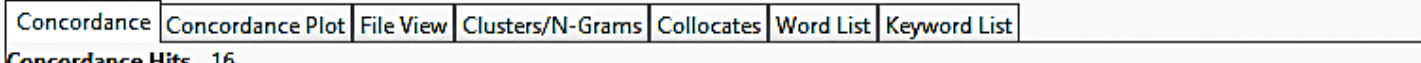 } \\
\hline \multicolumn{3}{|c|}{ Concordance Hits 16} \\
\hline Hit & WIC & File \\
\hline he) & eyare always sensitive about sharing information about new diseases. In fact, some & sample 1-.txt \\
\hline 2 & have a standardized way to collect information about the clinical presentation, the $\varsigma$ & sample 2-.txt \\
\hline 3 & and cooperation starts from sharing information and that $\times 92 \mathrm{~s}$ what we & sample 3.txt \\
\hline 4 & ? But my understanding is that the information around the epidemic was being trac & sample 1-.txt \\
\hline 5 & it immediately, and sharing line list information, but not only that, the commitment & sample 3.txt \\
\hline 6 & become established. We are sharing information, guidelines, and tools in real time & sample 1-.txt \\
\hline | 7 & really make sure, to really share information in real time. That will protect & sample 3.txt \\
\hline 8 & f respiratory and hand hygiene. Much information is available on that on our & sample 1-.txt \\
\hline 9 & obviously a very active outbreak and information is being updated and changing by & sample 1-.txt \\
\hline 10 & ional information on the risk, rational information on how to manage that risk & sample 1-.txt \\
\hline $\mid 11$ & Wuhan. What we need is more information on that in terms of the & sample 2-.txt \\
\hline 12 & together? How do we share rational information on the risk, rational information on & sample 1-.txt \\
\hline 13 & in terms of the amount of information that is been published by the & sample 1-.txt \\
\hline 14 & evidence. There will never be enough information to make a perfect decision, but & sample 1-.txt \\
\hline 15 & nd cooperation. It starts from sharing information. When a case crosses to another & sample 3.txt \\
\hline 16 & so that they are sharing their information, who have & sampl \\
\hline
\end{tabular}

Table (24): frequency of "information" 
According to table (26); the lexeme "collaboration" is repeated 8 times and collocates with "global" and "further" twice for each. The lexeme "expert" reiterates 4 times, while the plural "experts" is repeated 16 times in tables (27) and (28), respectively. The plural form collocates with "networks" in (7 and 3); "Taiwanese" in (15 and 9); "international" in $(14,12$, and 8); and with "Chinese" in $(2,10,11$, and 13).

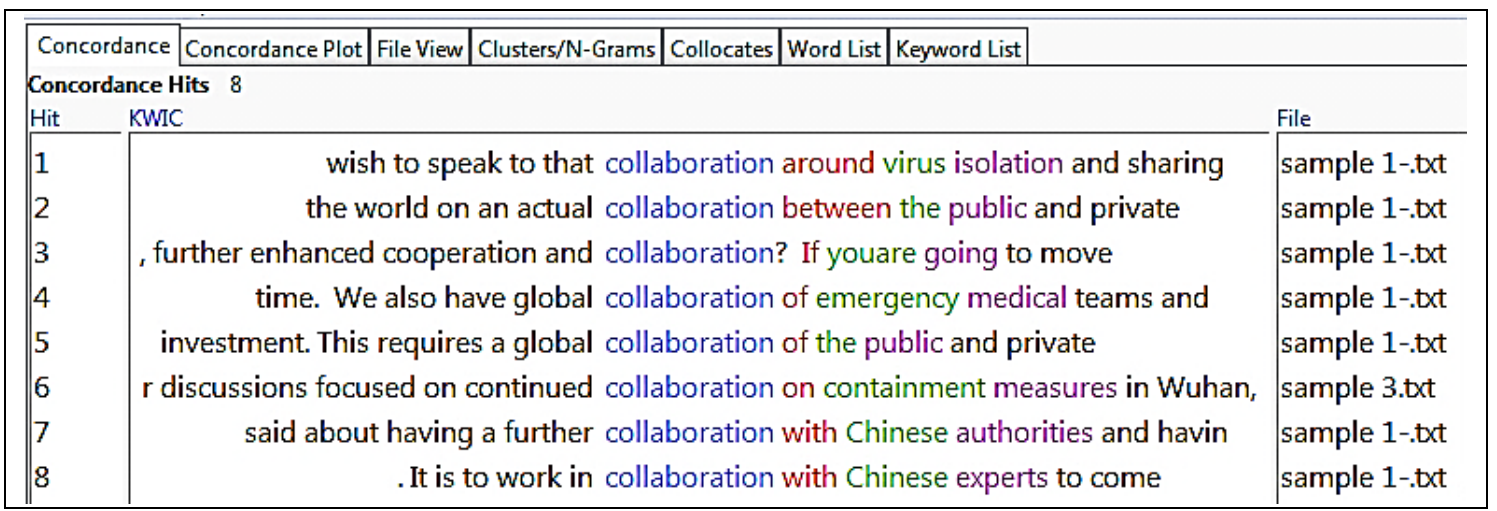

Table (26): frequency of "collaboration"

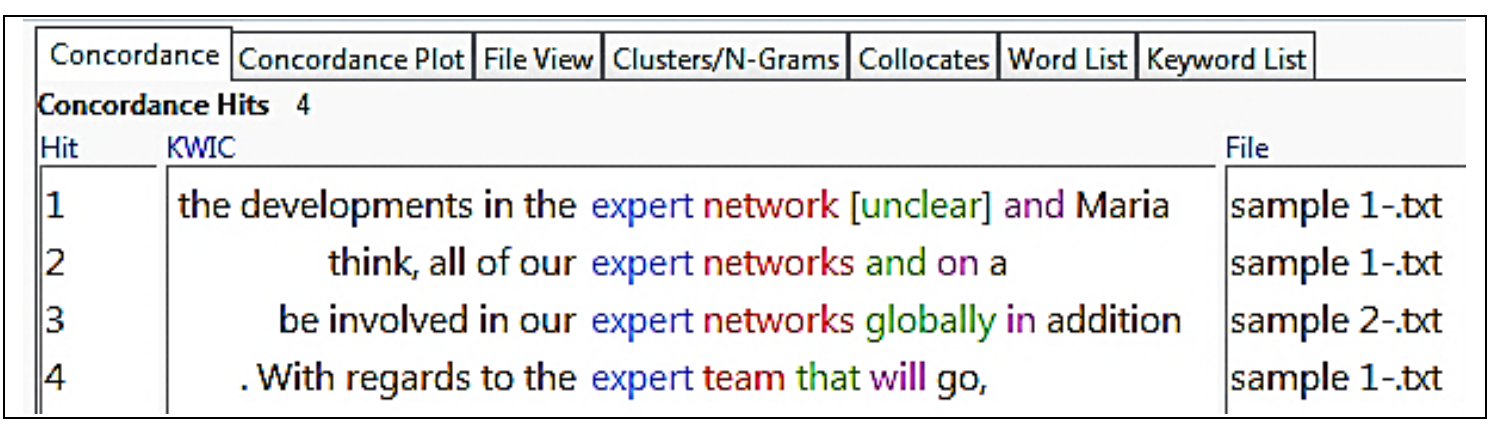

Table 27: frequency of "experts"

\begin{tabular}{|c|c|c|}
\hline Concordance & \multicolumn{2}{|l|}{\begin{tabular}{|l|l|l|l|l|l|} 
Concordance Plot & File View & Clusters/N-Grams & Collocates & Word List & Keyword List \\
\end{tabular}} \\
\hline \multicolumn{3}{|c|}{ Concordance Hits 16} \\
\hline KWIC & & File \\
\hline $\mid 1$ & ackers $_{s}$ modelers logisticians $_{s}$ supply chain experts, and many others from the public and & sample 1-.txt \\
\hline || 2 & severity, but I might add that Chinese experts are involved in almost, I think, all & sample 1-.txt \\
\hline $\mid 3$ & our expert networks globally in addition to experts from around the world who work on & sample 2-.txt \\
\hline 4 & from the bottom up in terms of experts from China, Taiwan, or Taipei Municipality. & sample 1-.txt \\
\hline 5 & I said, these networks of experts include experts from China working directly on the respons & sample 1-.txt \\
\hline 6 & may identify that can work as independent experts if we lack expertise in WHO, but & sample 3.txt \\
\hline || 7 & responses. As I said, these networks of experts include experts from China working directly & sample 1-.txt \\
\hline ider & ering that. We have already consulted some experts international inside WHO and outside and $v$ & sample 3.txt \\
\hline $\mathrm{n}_{s}$ & or Taipei Municipality. We have Taiwanese experts involved in all of our consultations \x96 & sample 1-.txt \\
\hline 10 & go to China and work with Chinese experts to better understand disease transmission $a$ & sample 1-.txt \\
\hline 11 & is to work in collaboration with Chinese experts to come to a better common understanding & sample 1-.txt \\
\hline 12 & have agreed to a mission of international experts to go to China and work with & sample 1-.txt \\
\hline 13 & , to observe, and to work with Chinese experts to learn as much as we can & sample 1-.txt \\
\hline 14 & WHO will lead a team of international experts to visit China as soon as possible & sample $3 . t x t$ \\
\hline 15 & ecifically and maybe more to the Taiwanese experts we have. Number one, it is very & sample 1-.txt \\
\hline 16 & $2 \mathrm{~s}$ what we recommend because the WHO experts will be those who work for WHO & sample 3.txt \\
\hline
\end{tabular}

Table (28): frequency of "experts" 


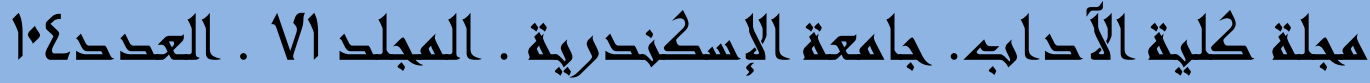

The expository $\mathrm{CP}$ about the transmission of the virus, the number of infected cases; and the precautions to prevent the virus are important topics in the institutional scientific register about pandemics. This is achieved by the functional use of lexemes such as "cases". Table (29) reveals that the lexeme "cases" is repeated 47 times. It collocates with "countries" 11 times in (19), (20), (21), (24), and (36), and the past participle adjective "imported" 5 times in $(4,8,26,42$, and 46). The prepositional phrase "in cases" is used to post-modify "numbers" "export", "majority" "importation", and "levels". Moreover, the lexeme "cases" collocates with "confirmed" in (10, 20, and 25); and with the verb "identify" in (2 and 35). 


\begin{tabular}{|c|c|c|}
\hline \multicolumn{3}{|c|}{ Concordance Hits 47} \\
\hline Hit & KWIC & \multirow{2}{*}{$\begin{array}{l}\text { File } \\
\text { sample 1-.txt }\end{array}$} \\
\hline 1 & response is underway to track cases and contacts and try to interrupt & \\
\hline 2 & to be able to quickly identify cases and, in doing so, $_{s}$ identify, isolate, & sample 2-.txt \\
\hline 3 & alth. The continued increase in cases and the evidence of human-to- & sample 3.txt \\
\hline 4 & ries that already have imported cases and we still have an opportunity & sample 1-.txt \\
\hline 5 & this is why we are seeing cases and why the evolution of this & sample 2-.txt \\
\hline 6 & is that the majority of those cases apart from six are associated with & sample 1-.txt \\
\hline 7 & hose, the vast majority of those cases are associated still with travel to & sample 1-.txt \\
\hline 8 & e countries who have imported cases are clearly at full alert. Those & sample 1-.txt \\
\hline 9 & Ilness, but still $20 \%$ of reported cases are reported as severe and $2 \%$ of & sample 1-.txt \\
\hline 10 & as severe and $2 \%$ of confirmed cases are reported to have died. The & sample 1-.txt \\
\hline 11 & tend to focus on the severe cases because those are the individuals who & sample 2-.txt \\
\hline 12 & around the world in terms of cases being reported of anything, but I & sample 1-.txt \\
\hline 13 & it and we may see more cases, but for now it $\backslash x 92 \mathrm{~s}$ & sample 3.txt \\
\hline 14 & as really not meaningful. A few cases crossed to Uganda, but they were & sample 3.txt \\
\hline 15 & Insmission, isolating patients in cases early, making sure that that detection & sample 2-.txt \\
\hline 16 & dence of increasing numbers of cases, evidence for human-to-human transmissi & sample 1-.txt \\
\hline 17 & a standardized data format for cases, for contacts, both aggregate and disag & sample 1-.txt \\
\hline 18 & taken to prevent the export of cases. For that China deserves our gratitude & sample 3.txt \\
\hline 19 & u figures. 68 outside China, 68 cases in 15 countries because the epicenter $\mathbf{i}$ & sample 3.txt \\
\hline 20 & na there are only 68 confirmed cases in 15 countries, which is $1 \%$ of total, & sample 3.txt \\
\hline 21 & our concern is if we have cases in countries who have a weak & sample 3.txt \\
\hline 22 & their support. For example, the cases in Germany reported yesterday originate & sample 3.txt \\
\hline 23 & hot only helping to manage the cases in its own country but is & sample 1-.txt \\
\hline 24 & Intries on investigating suspect cases in two countries in Africa and & sample 1-.txt \\
\hline 25 & there are now 6,065 confirmed cases, including 5,997 in China, representing & sample 3.txt \\
\hline 26 & g countries that have imported cases, including some very large ones. Theyar & sample 1-.txt \\
\hline 27 & he second question about mild cases is, as surveillance improves, as detect & sample 2-.txt \\
\hline 28 & cases $_{x}$ that rapid acceleration in cases is of concern and in a & sample 1-.txt \\
\hline 29 & countries. Of note within those cases is that the majority of those & sample 1-.txt \\
\hline 30 & There are signs of a few cases of human-to-human transmission outside & sample 3.txt \\
\hline 31 & been very open in reporting its cases on a daily basis to us. & sample 1-.txt \\
\hline 32 & to date we have only seen 68 cases outside China and no deaths is & sample 3.txt \\
\hline 33 & no deaths. The vast majority of cases outside China have a travel history & sample 3.txt \\
\hline 34 & ing for individuals in additional cases. Outside of China we have seen & sample 2-.txt \\
\hline 35 & he sequencing to identify these cases quickly. So this is why we & sample 2-.txt \\
\hline 36 & I China. However, there are 71 cases reported in 15 other countries. Of note & sample 1-.txt \\
\hline 37 & selves if there is importation of cases. So they need to really have & sample 3.txt \\
\hline 38 & the overwhelming majority of cases still being reported from China. Howeve & sample 1-.txt \\
\hline 39 & action and be ready for any cases that come either from the original & sample 1-.txt \\
\hline 40 & e worrying. The acceleration in cases, that rapid acceleration in cases is & sample 1-.txt \\
\hline 41 & t quantities for certain levels of cases that they might expect. So those & sample 1-.txt \\
\hline 42 & 5 countries who have imported cases. They have to stop transmission. Some & sample 1-.txt \\
\hline 43 & engaged all countries that have cases to be involved in our expert & sample 2-.txt \\
\hline 44 & all member states who import cases to share with us on a & sample 1-.txt \\
\hline 45 & manage potential coronavirus cases tomorrow elsewhere. We are helping othe & sample 1-.txt \\
\hline 46 & untries who have not imported cases will obviously need to look at & sample 1 -.txt \\
\hline 47 & representing almost $99 \%$ of all cases worldwide. 132 people have lost their I & sample 3.txt \\
\hline
\end{tabular}
Table (29): frequency of "cases"

The lexeme "transmission" is repeated 25 times in table (30). It collocates with the compound adjective "human-to-human" 9 times in (2, $9,10,11,15,16,17,21$ and 25). Furthermore, it collocates with the verbs "understand" in (1, 5, and 14), and "stop" in (4 and 19). Finally it 
collocates with the nouns "evidence" in (16 and 21), and "chains" in (3, 24, and 4).

\begin{tabular}{|c|c|c|}
\hline \multicolumn{3}{|c|}{ Concordance Hits 25} \\
\hline Hit & KWC & File \\
\hline 1 & se experts to better understand disease transmission and to better understand clinical sever & sample 1-.txt \\
\hline 2 & some example of human-to-human transmission as Dr Tedros mentioned ${ }_{r}$ but it & sample 2-.txt \\
\hline 3 & WHO believe that these chains of transmission can still be interrupted. This disease & sample $1-. \mathrm{txt}$ \\
\hline 4 & and other governments $\backslash \times 96$ stop those transmission chains. We must make that $\times 85$ & sample 1-.txt \\
\hline 5 & better understand and characterize the transmission characteristics of this virus, the clin & sample 2-.txt \\
\hline 6 & is our goal. With regards to transmission, Chinese authorities told us during the & sample 2-.txt \\
\hline 7 & people talk about ROs and transmission dynamics and all of that, they & sample 1-.txt \\
\hline 8 & or put into context the current transmission dynamics. So in a situation like & sample 1-.txt \\
\hline 9 & we have witnessed human-to-human transmission. If this gets into a country & sample 3.txt \\
\hline 10 & we see the human-to-human transmission in three countries, we are reconvening & sample $3 . t x t$ \\
\hline 11 & 68 and especially the human-to-human transmission in three countries worries us -- in & sample 3.txt \\
\hline 12 & in other provinces in China where transmission is less intense and the numbers & sample 1-.txt \\
\hline 13 & outbreak and the further development of transmission is of great concern and has & sample $1-. \mathrm{txt}$ \\
\hline 14 & spread. So what we understand about transmission is that this is being transmitted & sample 2-.txt \\
\hline 15 & focusing on limiting human-to-human transmission, isolating patients in cases early, mak & sample 2-.txt \\
\hline 16 & the evidence of human-to-human transmission outside China are of course both & sample 3.txt \\
\hline 17 & few cases of human-to-human transmission outside China in three countries, which & sample $3 . t x t$ \\
\hline 18 & and taking into consideration reducing transmission, reducing morbidity and mortality $\times 85 \mathrm{t}$ & sample 2-.txt \\
\hline 19 & imported cases. They have to stop transmission. Some of them are doing that & sample 1-.txt \\
\hline 20 & ommunity investigations, how to manage transmission studies, how to manage clinical trials, & sample 1-.txt \\
\hline 21 & cases $_{x}$ evidence for human-to-human transmission that has occurred outside of China. & sample 1-.txt \\
\hline 22 & data on an epidemic the asymptomatic transmission. That requires very specific household & sample 1-.txt \\
\hline 23 & droplets and that also can have transmission through direct physical contact between & sample 2-.txt \\
\hline 24 & and try to interrupt chains of transmission. We have the 15 countries who have & sample 1-.txt \\
\hline 25 & that we limit human-to-human transmission x96 not only in healthcare facilities, & sample 2-.txt \\
\hline
\end{tabular}

Table (30): frequency of "transmission"

Other lexemes used to achieve the $\mathrm{CP}$ of expressing the transmission of the virus are "outbreak" which is repeated 20 times in table (31), and "emergency" which is repeated 22 times in table (32). The latter collocates with "committee" in $(2,3,4,5,6,7,8,9,10$, and 11), and with "health" in (1, 18 and 19). 


\begin{tabular}{|c|c|c|}
\hline & \multirow[b]{2}{*}{ File } \\
\hline \multicolumn{2}{|c|}{$\begin{array}{l}\text { Concordance Hits } 20 \\
\text { Hit KWIC }\end{array}$} & \\
\hline 1 & hers who work from the Global Outbreak Alert \& Response Network, from th & sample 1-.txt \\
\hline 2 & d. Our colleagues in the Global Outbreak Alert \& Response Network, many c & sample 1-.txt \\
\hline 3 & have lost their lives to this outbreak, all of them in China. Our & sample 3.txt \\
\hline 4 & hd in Wuhan to understand the outbreak and direct the response. China x 92 & sample 3.txt \\
\hline 5 & x92s detailed knowledge of the outbreak and his personal involvement in the & le 3.txt \\
\hline 6 & s the response to the outbreak and how WHO can support be & t.xt \\
\hline 7 & is still obviously a very active outbreak and information is being updated a & le 1-.txt \\
\hline 8 & terms of the evolution of the outbreak and the further development of trar & le 1 -.txt \\
\hline 9 & of the outbreak. Managing the outbreak at the epicenter helps us from & sample 3.txt \\
\hline 10 & & \\
\hline 11 & e them on whether the current outbreak constitutes a public health emergen & e 1-.txt \\
\hline 12 & ctors. WHO is monitoring this outbreak every moment of every day. We & sample 3.txt \\
\hline 13 & puidance that is evolving as this outbreak evolves. Yes. So we have reports & sample 2-.txt \\
\hline 14 & virus came from and why this outbreak happened when it did. & sample 2-.txt \\
\hline 15 & the potential for a much larger outbreak. I have therefore decided to reconve & sample 3.txt \\
\hline 16 & focus on the epicenter of the outbreak. Managing the outbr & \\
\hline 17 & 9 to advise me on whether the outbreak represents a public health emergen & sample 3.txt \\
\hline 18 & the epicenter helps us from the outbreak spreading to the rest of the & sample 3.txt \\
\hline 19 & asing the understanding of the outbreak to guide global response eff & sample 3.txt \\
\hline 20 & ling together to respond to this outbreak. We are at an important juncture & sample 1-.txt \\
\hline
\end{tabular}

Table (31): frequency of "outbreak"

\begin{tabular}{|l|ll|}
\hline $\begin{array}{l}\text { Concordance Hits } 22 \\
\text { Hit }\end{array}$ & KWI & File \\
1 & declaring a global public health emergency and the merits of any temporary & sample 1-.txt \\
2 & a concerted discussion with the Emergency Committee can deliver, but the first & sample 1-.txt \\
3 & hat the discussion amongst the Emergency Committee is all about. What are & sample 1-.txt \\
4 & rave received, in advance of the Emergency Committee last week, a detailed disaggr & sample 1-.txt \\
5 & ternational Health Regulations Emergency Committee on novel coronavirus 2019 to & sample 3.txt \\
6 & ternational Health Regulations Emergency Committee on the new novel coronavirus, & sample 1-.txt \\
7 & the DG is bringing back the Emergency Committee to consider tomorrow. Having & sample 1-.txt \\
8 & with us in advance of the Emergency Committee tomorrow and we are hoping & sample 1-.txt \\
9 & that together and I believe the Emergency Committee tomorrow will consider the me & sample 1-.txt \\
10 & ny recommendations from the Emergency Committee will help us to be & sample 3.txt \\
11 & e authorities told us during the Emergency Committee you saw in the EC & sample 2-.txt \\
12 & to cope with all of the emergency demands. It has been tough and & sample 1-.txt \\
13 & eaking today with our regional emergency director and we have been in & sample 1-.txt \\
14 & is driving a new wave of emergency events. The WHO and Dr Tedros & sample 1-.txt \\
15 & nment with a highly organized emergency management structure. The challenge is & sample 1-.txt \\
16 & so have global collaboration of emergency medical teams and EMTs from China & sample 1-.txt \\
17 & \& Response Network, from the Emergency Medical Teams network, and many other & sample 1-.txt \\
18 & reak constitutes a public health emergency of international concern. His decision & sample 1-.txt \\
19 & are dealing with a public health emergency of international concern and advise the & sample 1-.txt \\
20 & reak represents a public health emergency of international concern and to seek & sample 3.txt \\
21 & ation to address a global health emergency. President Xi and I agreed that & sample 3.txt \\
22 & you know, the capacity of the emergency program in WHO especially since Ebola & sample 3.txt \\
\hline
\end{tabular}

Table (32): frequency of "emergency" 
The epistemic stance of doubt prevails in the three samples under analysis. It reflects the addressors' caution and speculation towards the epidemic transmission, symptoms, and invention of the vaccine in the future. The modal verb "may" prevails in the three samples with a frequency of 17 times, as table (33) proves. The addressors express their doubts towards the influence of security incidences on Ebola spread; possible reasons for the absence of the epidemic infection among the health workers in Chinese hospitals, stopping the spread of the epidemic in the future, and possible financial cooperation with other countries to control the epidemic. Moreover, collaborating with China to prevent the epidemic in the future, mortality rates because of the epidemic, symptoms of coronavirus in confirmed cases are topics expressed cautiously using the modal verb "may".

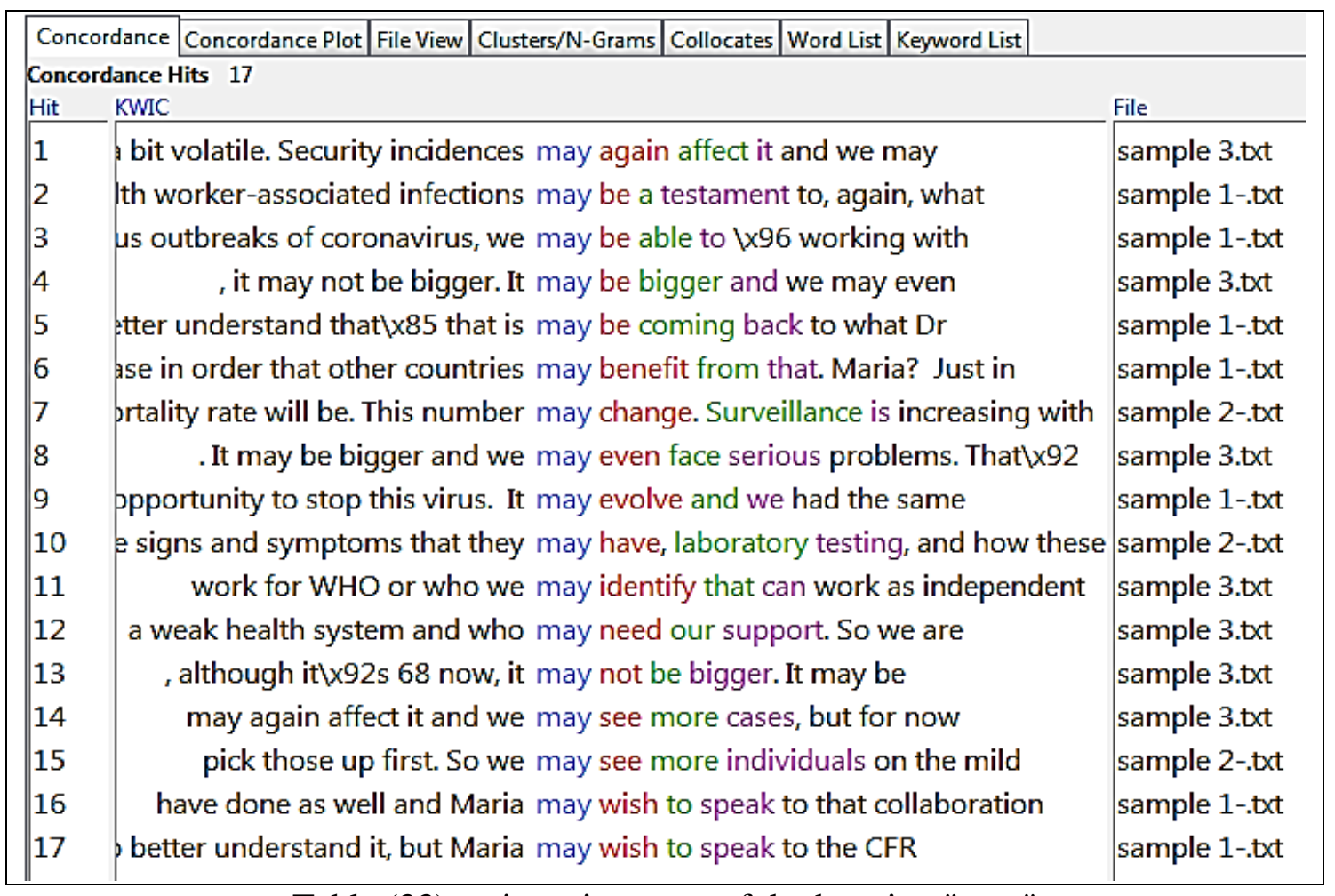

Table (33): epistemic stance of doubt using "may"

The second tool to express doubt is the verb "think" which is repeated 15 times in table (34). The addressors use the verb "think" to suggest strategies to control coronavirus, for example, the Traffic Light approach, the Something Must be Done Club, and the approach of Focusing on the Epicenter. Other devices of epistemic stance of doubt in the register under analysis are "probably" and "potentially" in Sample (1). 


\begin{tabular}{|c|c|c|}
\hline \multicolumn{3}{|c|}{ 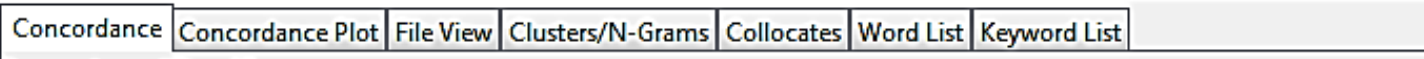 } \\
\hline \multirow{2}{*}{\multicolumn{3}{|c|}{ 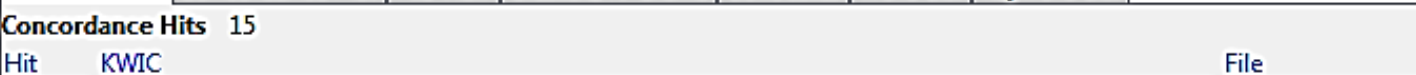 }} \\
\hline Hit & KWIC & \\
\hline 1 & experts are invo & sample 1-.txt \\
\hline 2 & around the national securit & sample 1-.txt \\
\hline 3 & olitical situation to limit cap & sample 3.txt \\
\hline 4 & . Can I just add be & sample 1-.txt \\
\hline 5 & in this res & e 1-.txt \\
\hline 6 & shared with the world. So I think it is very important to understanı & sample 1-.txt \\
\hline 7 & I think it is very earl & sample 2-txt \\
\hline 8 & government at all levels. Personally I think myself and the Director General & sample 1-.txt \\
\hline 9 & not: so nothing in betv & sam \\
\hline 10 & important and to do that I think the & sample 3.txt \\
\hline 11 & $\mathrm{PHEIC}_{r}$ either green or red. I think we have to now revise that. & sample 3.txt \\
\hline 12 & having that concern, but I do think we need to also focus on & sample 1-.txt \\
\hline 13 & you. Yes. So on Ebola I think we took the same approach: foct & sample 3.txt \\
\hline 14 & terms of finance I don't think will be a problem, but make & sample 3.txt \\
\hline 15 & relation to the effective measures we think works and if there & sample 3.txt \\
\hline
\end{tabular}

Table (34): epistemic stance of doubt using "I think"

The second observed kind of stance is the epistemic stance of certainty. It is expressed by the adverbial "certainly" which prevails in Sample (1) with frequency of 3 times as table (35) shows.

\begin{tabular}{||l|ll|l|}
\hline $\begin{array}{l}\text { Concordance Hits } 3 \\
\text { Hit }\end{array}$ & KWC & File \\
\hline 1 & what you mean by that because certainly if you track the Wuhan website, & sample 1-.txt \\
2 & with some of the numbers, but certainly the government authorities in Wur & sample 1-.txt \\
3 & put the health of people first. Certainly, the levels of meetings and the & sample 1-.txt \\
\hline
\end{tabular}

Table (35): the epistemic stance of certainty by using "certainly"

The addressor uses the adverbial "certainly" to commit himself to the reality of the event's occurrence, for example, the alerts announced on Wuhan websites, the daily numbers announced by the government authorities in Wuhan, the commitment of the Chinese government to control the epidemic are events that toke place according to the addressor.

In addition, the adverbial "obviously" is repeated 6 times, as table (36) exhibits. Among the topics assured by the adverbial "obviously" are considering the epidemic as an active one, considering the visit to China as "a short mission", defining the coronavirus as a respiratory disease, and considering preparedness and readiness as the first priorities of countries with imported cases. 


\begin{tabular}{|c|c|c|c|}
\hline \multicolumn{4}{|c|}{\begin{tabular}{|l|l|l|l|l|l|} 
Plot & File View & Clusters/N-Grams & Collocates & Word List & Keyword List \\
\end{tabular}} \\
\hline \multicolumn{4}{|c|}{ Concordance Hits 6} \\
\hline Hit & \multicolumn{2}{|l|}{ KWC } & File \\
\hline 1 & \multirow{2}{*}{\multicolumn{2}{|c|}{$\begin{array}{l}\text { we know at this stage: this is still obviously a very active outbreak and information is being } \\
\text { what we learnt on the trip, it was obviously a very short mission, but what I took }\end{array}$}} & sample 1-.txt \\
\hline 2 & & & sample 1-.txt \\
\hline 3 & \multirow{2}{*}{\multicolumn{2}{|c|}{$\begin{array}{l}\text { are reported to have died. The disease is obviously mainly respiratory disease passing via droplets } \mathrm{f} \\
\text { countries who have not imported cases will obviously need to look at their readiness and preparedness. }\end{array}$}} & sample 1-.txt \\
\hline 4 & & & sample 1-.txt \\
\hline 5 & \multirow{2}{*}{\multicolumn{2}{|c|}{$\begin{array}{l}\text { EC tomorrow. Just might I add that well, obviously the evidence needs to come in. The fact } \\
\text { y Committee can deliver, but the first thing obviously which the committee will need to consider is }\end{array}$}} & sample 1-.txt \\
\hline 6 & & & sample 1-.txt \\
\hline
\end{tabular}

Table (36): epistemic stance of certainty by using "obviously"

Finally, the adverbial "clearly" conveys the epistemic stance of certainty in Sample (1) with a frequency of 4 times in table (37). Among the topics assured by the adverbial "clearly" are the current response to the epidemic inside and outside China, the directions of WHO to make sick people get the necessary health care, and the readiness of the countries of imported cases.

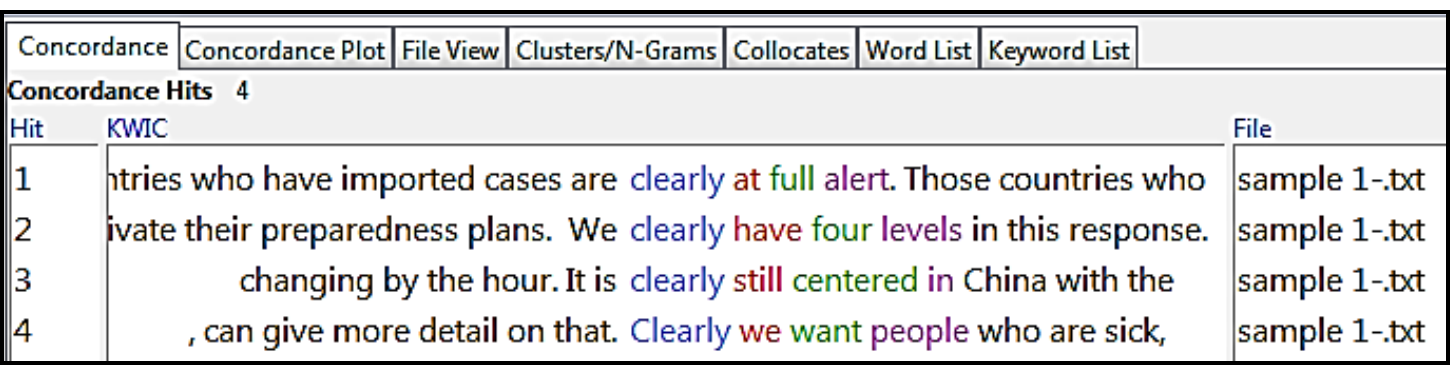

Table (37): epistemic stance of certainty by using "clearly"

In Sample (2), the only token of the epistemic stance of certainty is the adjective "sure" in "I am sure". It is used to express the existence of misinformation about the epidemic in "I am sure you have seen that there's a lot of misinformation that's out there".

In Sample (3), the epistemic stance of certainty is expressed by the adverb "of course" in 4 times, as table (38) reveals.

\begin{tabular}{|c|c|c|}
\hline \multicolumn{3}{|c|}{ 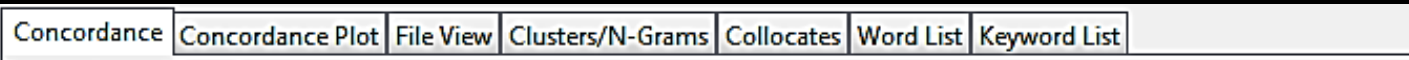 } \\
\hline \multicolumn{3}{|c|}{$\begin{array}{l}\text { Concordance Hits } 4 \\
\text { Hit } \quad \text { KWIC }\end{array}$} \\
\hline Hit & KWC & File \\
\hline $\mid 1$ & transmission outside China are of course both deeply concerning. Also, the & sample 3.txt \\
\hline 2 & I will take on the evacuation. Of course, decisions on evacuating citizens is & sample 3.txt \\
\hline $\mid 3$ & doing its best and that helps. Of course, in addition to that, we & sample 3.txt \\
\hline 4 & media issues around the world. Of course people are concerned. Why would & sample 1-.txt \\
\hline
\end{tabular}

Table 38: epistemic stance of certainty by using "of course"

Based on table (38), the addressor is certain about the increase of cases outside China, the decisions of evacuating citizens as a national concern of countries, the request of WHO for the member states cooperation, and the anxiety of people because of the epidemic as a 


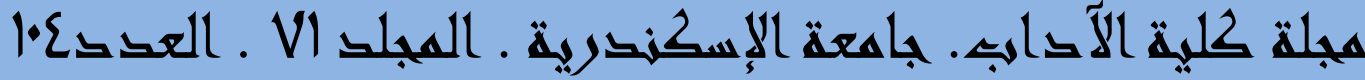

normal reaction. The adverbial "exactly" is used once to commit the addressor to the certainty of the seriousness of WHO in dealing with the new epidemic.

Based on tables (39) and (40), the epistemic stance of actuality and reality is expressed by the adverbials "actually" in 8 times and "really" in 13 times in the three samples under analysis. The adverbial "actually" is used to commit the speaker to certain issues as a matter of fact. For example, the collective attendance of the scientists to the conference, the scarcity of household studies, the Chinese reaction to coronavirus as a powerful factor in reducing coronavirus spread, and Margaret Chan as the actual reformer of WHO emergency program are among the topics that are expressed by the epistemic stance of actuality. The adverbial "really" commits the speaker to the reality of the propositional content of issues such as people's readiness only in dangerous situations, the reduction of Ebola in DRC, limiting human-to-human transmission of the epidemic as the first aim of WHO, and WHO's focus on the epicenter.

\begin{tabular}{|c|c|c|}
\hline \begin{tabular}{|l|l|l|} 
Concordance & Concordance Plot & File View \\
\end{tabular} & \begin{tabular}{rl|l|l|l|l|l|} 
rdance & Concordance Plot & File View & Clusters/N-Grams & Collocates & Word List & Keyword List \\
\end{tabular} & \\
\hline \multicolumn{3}{|c|}{ Concordance Hits 8} \\
\hline Hit & KWIC & File \\
\hline $\mid 1$ & re supposed to come together actually, all of us, but I was & sample $3 . t x t$ \\
\hline 2 & nowledge is very amazing. We actually ask in other countries to have & sample 3.txt \\
\hline $\mid$ & a few of which have been actually carried out. It would be impossible & sample 1 \\
\hline 4 & $h$ and again because its actions actually help in reducing the spread of & sample 3.txt \\
\hline 5 & do receive that and I have actually personally been in touch with our & sample 1-.txt \\
\hline $\mid 6$ & extremely well. All of them are actually taking good action, but some need & sample 1-.txt \\
\hline 7 & in 2014 has increased, thanks actually to Margaret Chan, who started the & sample 3.txt \\
\hline 8 & le phylogenetics of this and we actually trace back, we look back in & sample 2-.txt \\
\hline
\end{tabular}

Table (39): epistemic stance of actuality 


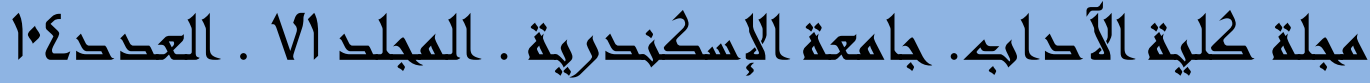

\begin{tabular}{|c|c|c|c|}
\hline \multicolumn{4}{|c|}{\begin{tabular}{|l|l|l|l|l|l|l|} 
Concordance & Concordance Plot & File View & Clusters/N-Grams & Collocates & Word List & Keyword List \\
\cline { 2 - 4 }
\end{tabular}} \\
\hline \multicolumn{4}{|c|}{ Concordance Hits 13} \\
\hline Hit & KWIC & & File \\
\hline $\mid 1$ & & of the issues, that people only really consider preparedness when we & sample 1-.txt \\
\hline ||2 & & there and now it $\times 92 \mathrm{~s}$ really down and we hope it will & sample 3.txt \\
\hline || 3 & & . So all of our guidance is really focusing on limiting human-to-r & sample 2-.txt \\
\hline 4 & & of new evidence, but what we really got a sense of was that & sample 1-.txt \\
\hline | 5 & & of cases. So they need to really have a thorough understanding & sample 3.txt \\
\hline || 6 & think & $k$ the traffic light approach would really help because the yellow would $k$ & sample 3.txt \\
\hline || 7 & & were taken care of. So we really invested in DRC and it was & sample 3.txt \\
\hline || 8 & & what we call on countries to really make sure, to really share inforn & sample 3.txt \\
\hline |I & & on the epicenter. The spread was really not meaningful. A few cases cros & sample 3.txt \\
\hline $\mid 10$ & & could be serious enough but not really red. So that $\backslash 92 \mathrm{~s}$ the & sample 3.txt \\
\hline $\mid 11$ & & countries to really make sure, to really share information in real time. $\mathrm{T}$ & sample 3.txt \\
\hline $\mid 12$ & & ve have agreed with China. China really takes it to heart and $\mathrm{WHO}_{\text {, }}$ & sample 3.txt \\
\hline $\mid 13$ & & take any opportunity. So this is really where science, public health, anc & sample 1-.txt \\
\hline
\end{tabular}

Table (40): epistemic stance of reality

The epistemic stance of source of knowledge is expressed in the three samples under analysis by the "subject-said-structure" with a frequency of 24 times, as table (41) shows. Out of the 24 times, 8 times reveal the addressor himself as the source of information using "as-I-said structure" and 16 times reveal another scientist as the source of information using "X-said or X-mentioned structures" with $\mathrm{X}$ referring to the proper name of the scientist. In all cases, the referent is one of the attending institutional addressors affiliated to WHO. Other adverbials used to express the source of information are "remarkably", "originally", "collectively", and "personally" in Sample (1). 


\begin{tabular}{|c|c|c|}
\hline \multicolumn{3}{|c|}{ Concordance Hits 24} \\
\hline Hit & KWIC & File \\
\hline 1 & coming back to what Dr Tedros said about having a further collaboration wi & i sample 1-.txt \\
\hline 2 & what Mike said or what Maria said and I hope you will bear & sample 3.txt \\
\hline 3 & , but the rest has already been said. Any recommendations from the Emer! & sample 3.txt \\
\hline 4 & contact. The source, as we have said before, is still unclear and the & sample 1-.txt \\
\hline 5 & on the coronavirus. Luckily, as I said earlier, the level of commitment from & sample 3.txt \\
\hline 6 & I fully agree with what Mike said. I don $\backslash x 92 t$ want to & sample 3.txt \\
\hline 7 & and we are $x 85$ as I said, in addition to issuing the disease & sample 1-.txt \\
\hline 8 & ie, from the president himself. I said it in my speech. The level & sample 3.txt \\
\hline 9 & uses that are available. As Mike said, it is very stable. What will & sample 2-.txt \\
\hline 10 & aspects of this epidemic $c_{r}$ as you said, Lisa, that are worrying. The accelerat & sample 1-.txt \\
\hline 11 & didn $x 92 t$ know what Mike said or what Maria said and I & sample 3.txt \\
\hline 12 & from such funding. As the DG said, our colleagues in China were very & sample 1-.txt \\
\hline 13 & and manage that process. As I said, thanks to those companies and institui & sample 1-.txt \\
\hline 14 & to consider tomorrow. Having said that, we do not know the & sample 1-.txt \\
\hline 15 & at could be problematic. As you said, the mobilization of member states, the & sample 3.txt \\
\hline 16 & to complement what Mike has said, the rapid sharing $x 85$ when we & sample 2-.txt \\
\hline 17 & jwers and those responses. As I said, these networks of experts include exp€ & sample 1 -.txt \\
\hline 18 & a more effective way. As I said, they are taking extraordinary measure & sample 1-.txt \\
\hline 19 & as soon as possible, but having said this, considering the last few days $\backslash$ & sample 3.txt \\
\hline 20 & ton of response and I have said to you, of the core press & sample 1-.txt \\
\hline 21 & we managed it, but as Mike said, [unclear] focusing on the epicenter, $\mathrm{p}$ & sample 3.txt \\
\hline 22 & pework, as the Director-General said, we have been working on a & sample 1-.txt \\
\hline 23 & it spreading? At the time I said, we have to base our actions & sample 1-.txt \\
\hline 24 & in doing that learning, as I said, we know that the intense epidemic & sample 1-.txt \\
\hline
\end{tabular}

Table (41): Epistemic stance of source of knowledge

In the data under analysis, the epistemic stance of limitations of propositional content appears in adverbials such as "mainly", "politically", "economically", "socially", "fundamentally", and "mostly", each of which is used once. Moreover, the adverbial "essentially" is used twice, and the adverbial "fully" is used 4 times to reveal the limitations of the propositional content of topics such as the precautions to prevent the epidemic spread, and the balance between media and ourselves. The unilateral measures which will take place politically, economically, and socially, the new epidemic as mainly a respiratory disease, the increase in the infected cases as the main reason for reconvening the committee, the readiness to coronavirus as the fundamental concern of WHO, and the close contact as the reason of infection are other topics expressed using adverbials of limitations.

In Sample (2), the epistemic stance of limitations is expressed by the adverbials "early" and "typically" which are used once and "globally" which is used twice. Among the topics expressed by adverbials of 
limitations in Sample (2) are the global increase in surveillance, the global engagement of countries with infected cases in Expert Networks, the examination about the methods of controlling the epidemic, and the ways of the epidemic spread as belonging to the early days of SARS. The adverbial "typically" limits WHO interest to the severe cases in epidemic outbreaks.

In Sample (3), epistemic stance of limitations appears in adverbials such as "internally", "externally", and "fully", each used once. Among the topics expressed using adverbials of limitations are "transparency" as a required principle "both internally and externally" and the addressor's full agreement in "... fully agree with what Mike said".

The least occurrence is of adverbials of attitude. This reflects the scientific objectivity where personal likes and dislikes have no influence. Nonetheless, very rare occurrences of attitude adverbials are detected in Sample (1) and Sample (3). In both samples, the adverbial "extraordinary" has 3 times. It is used to reveal the addressor's attitude as in "extraordinary challenge", "extraordinary measures", and "extraordinary steps". The adverbial "unfortunately" prevails only in Sample (1) in "unfortunately did not benefit from ... funding"; "unfortunately my memories goes back to SARS", and in "unfortunately we do not have the opportunity to say..." Finally, the adverbial "luckily" in Sample (3) reveals the addressors attitude in "... luckily the level of commitment from China is incredible". Table (42) summarizes the addressor's use of the epistemic stance in the three samples under analysis.

Sample (1)

\begin{tabular}{|c|c|c|c|}
\hline \multirow[t]{3}{*}{ Epistemic stance of doubt } & May & 7 & \multirow[t]{3}{*}{10} \\
\hline & Probably & 2 & \\
\hline & Potentially & 1 & \\
\hline \multirow[t]{3}{*}{ Epistemic stance of certainty } & Obviously & 6 & \multirow[t]{3}{*}{13} \\
\hline & Clearly & 4 & \\
\hline & Certainly & 3 & \\
\hline \multirow{2}{*}{$\begin{array}{l}\text { Epistemic stance of actuality and } \\
\text { reality }\end{array}$} & Actually & 3 & \multirow[t]{2}{*}{6} \\
\hline & Really & 3 & \\
\hline \multirow{5}{*}{$\begin{array}{l}\text { Epistemic stance of } \\
\text { knowledge }\end{array}$} & Remarkably & 1 & \multirow[t]{5}{*}{18} \\
\hline & Originally & 1 & \\
\hline & Collectively & 1 & \\
\hline & Said-structure & 13 & \\
\hline & Personally & 2 & \\
\hline Epistemic stance of limitation & Mainly & 1 & 12 \\
\hline
\end{tabular}




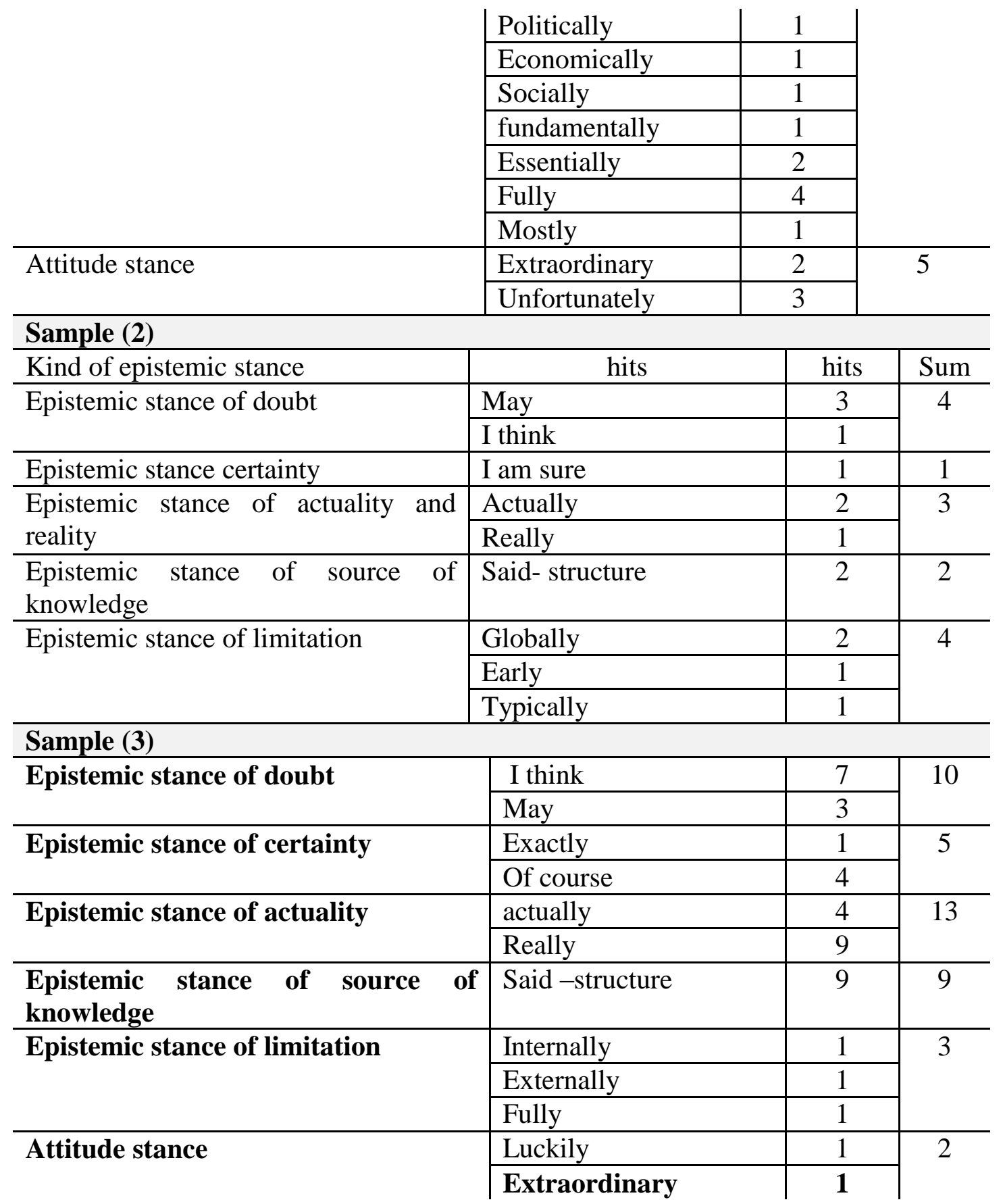

Table (42): epistemic stance

The previous table can be represented in the following chart: 


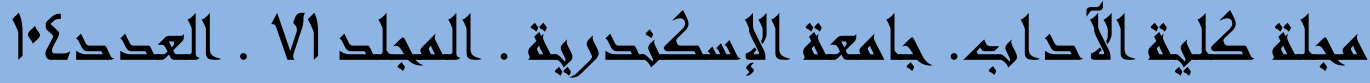

\section{Epistemic Stance}

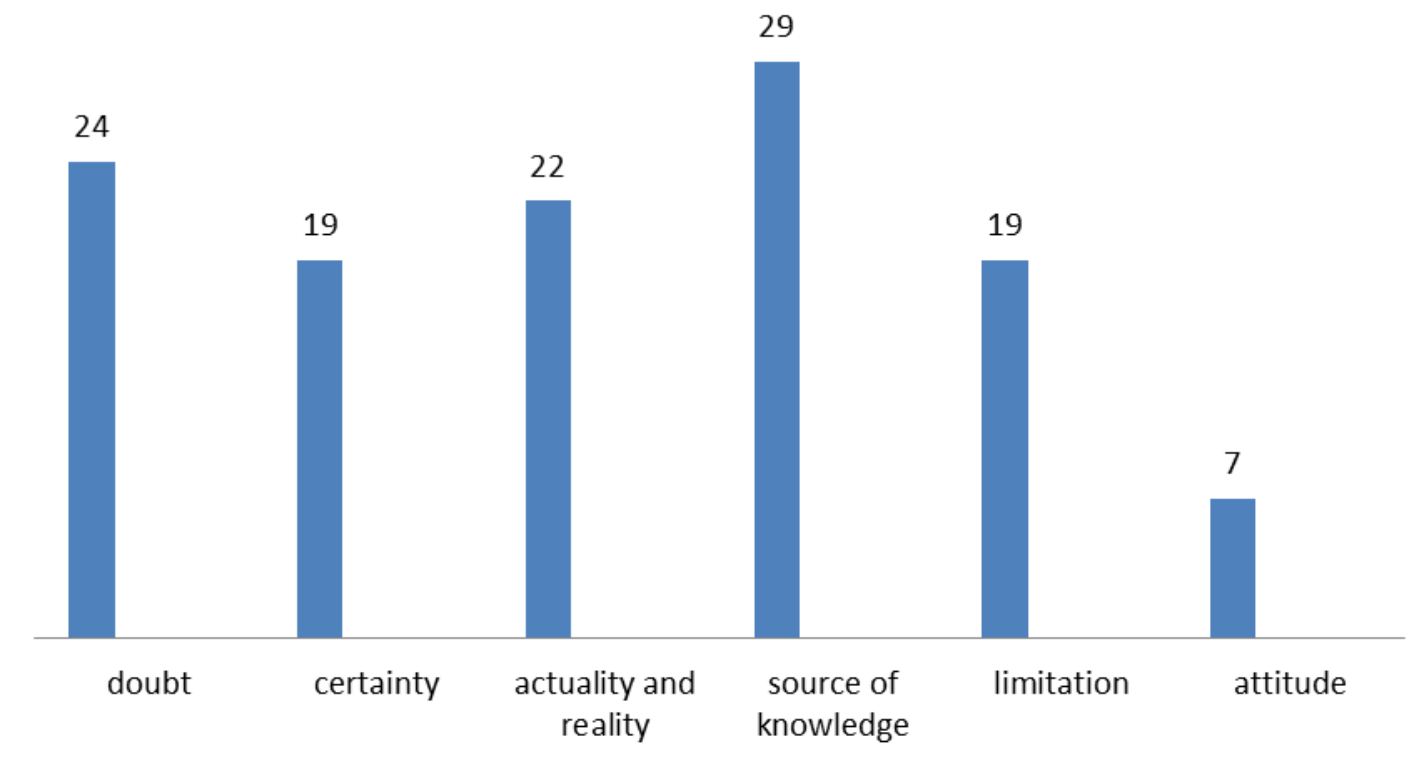

Figure (11): epistemic stance use

\section{Conclusion}

The aim of this research is to provide situational and linguistic analysis of the publicly-directed institutional scientific register. The situational features are shown in the participants' personal and social relations, the role of shared and specific knowledge in the comprehension; the influence of the channel and setting of communication, and the communicative purposes of the participants in the targeted register. The lexico-grammatical features appear in the participants' stance, and their vocabulary. Moreover, this paper investigates the influence of the situational features on the lexico-grammatical features used by the speakers in the register under investigation. Based on the qualitative and quantitative analysis of Covid-19 pandemic conference held on 29 January 2020 by WHO, the public-directed institutional scientific register about epidemics is characterized by the following:

First, it includes two kinds of institutional addressors: scientists and journalists. Both are identified by first names and professional affiliation. The professional affiliation is either to the organization where the scientists belong, or the news agencies that the journalists represent. Both kinds of participants share the same physical time and place. This is reflected in the participants' use of situation-dependent reference, namely adverbials of place and time. 
Since the scientists are the conference guests, they provide most of the contributions in the register under analysis. Because the sponsor of the conference is the health organization to which the scientists belong, they express their professional affiliation in their contributions by using certain linguistic devices and features. Among these distinctive linguistic features is the first person plural pronoun. It is used to convey the communicative purposes of the sponsoring health organization. The descriptive $\mathrm{CP}$ is the currently exerted efforts by the sponsoring health organization in stopping and sharing information about the new epidemic. This is achieved via using three structures: "we-are structure"; "we-have structure"; and we-have-been structure. The "we-are structure" is the most frequently used kind.

The second $\mathrm{CP}$ of the register under analysis is to express the institutional attitude towards health procedures or policies taken by one country. This is achieved by the functional use of attitudinal stance adverbials, such as "extraordinary", "luckily", and "unfortunately", to describe the Chinese response to the epidemic corona virus.

Adverbials expressing the source of knowledge are the most frequently used kind. This is attributed to the addressors' desire to appear as accurate, precise, and exact. It is mainly conveyed by "I-said" structure and "X-said" or "X-mentioned" structure where X refers to one of the attending institutional addressors affiliated to the health organization.

Adverbials of doubt have the second frequency. They are used to express the scientists' doubts about scientific issues of the epidemic, such as symptoms, ways of transmission, and vaccines. This reflects the skeptic and uncertain nature of science and the in-progress researches about the epidemic.

Adverbials of actuality and reality have the third frequency of occurrence. They are used to describe the current state of affairs of the new epidemic. Adverbials of certainty are used by the scientists to express actions or events taken by the sponsoring organization to control the epidemic transmission and share data about the epidemic sequencing. The least used kind is the attitude adverbials. This is attributed to the objectivity, impartiality, and integrity of science.

The future planned institutional aim of the sponsoring organization is the third CP. This is achieved by using five linguistic structures: "we-will" structure, "we-may" structure, "we-can" structure, "we-need" structure, and "we-have" structure. Describing the current state of affairs of the new epidemic is the third CP. It is achieved by using 
"we-don't" structure. It is observed that the first person plural pronoun is the shared linguistic constituent in all the previously mentioned linguistic structures. The KIC tool shows that the first person plural pronoun "we" is used to achieve the promotional aims of the sponsoring health organization. The informative CP appears where the scientists inform the public about the precautions to prevent the epidemic.

The second person plural pronoun "you" is the second most frequent pronominal use. It is used by the participants to direct their contributions to the addressees. It reflects the interactiveness of the public-directed institutional register of scientists about epidemics.

The functional use of the question-answer pattern reflects the interactiveness of the register under analysis. This interactiveness is of an unequal degree for the participants: journalists only have the right to ask, not to answer or discuss; while scientists only have the right to answer, not to ask. This inequality reflects the limited degree of interactiveness of the register under investigation. Therefore, the question pattern is mainly used by the journalists' while the declarative sentences are mainly used by the scientists. The exceptional cases appear in the journalists' use of declarative sentences to introduce themselves, to remind the addressees of a fact or event relevant to the directed question; or to specify the addressee by his name. For the scientists, the exceptional cases are rhetorical questions and the repetition of previously mentioned questions in similar epidemic cases in the past.

The only $\mathrm{CP}$ of the journalists is of an interrogative nature. They request information about the exerted efforts to stop and to prevent the new epidemic. This is achieved by the functional use of the question pattern which linguistically varies between the direct, indirect, and yes/no question. The indirect question is employed by the journalists to reflect the high level of formality of the register under investigation, and to appear as more polite. It is composed of linguistic structures such as "could you", "would you", "I wonder if I", which are followed by whword. The direct question form targets information about the number of infected, reported, and suspected cases, the procedures suggested for controlling the virus, and the future expectations of the organization. The third category of questions is the yes/no question in which the most frequent operator is verb to be, followed with verb to do, and the least used operator is the modal verb. 
Socially, the scientists' contributions are characterized by a high degree of authority and credibility. This is attributed to the specialized knowledge of the scientists in epidemics and their professional affiliation to the sponsoring health organization.

Regarding the context of utterance, general and specific knowledge has an essential role in understanding the register under investigation. General knowledge appears in the addressors' reference to facts that are well-known to the addressees. These well-known facts are usually about events, policies, strategies, and committees that belong to the sponsoring organization. Conversely, specific knowledge between the participants appears in the numerous scientific abbreviations that prevail in the three samples under analysis and the scientific vocabulary.

Regarding the time of production, the journalists do have a time to prepare their questions while the scientists do not. This is obvious in the scientists' incomplete sentences where the predicate and the object are missing. Finally, the scientists' vocabulary is used functionary to convey the CPs of the register under analysis. This is clear in the nouns and adjectives that reiterate in the three samples.

As the current research is limited to one international conference of WHO, potential areas for future research are the analysis of a larger sample to generalize the findings of the current study. While Biber ad Conrad (2019) approach for register analysis is the only applied approach in this study, applying other approaches of register analysis on WHO register of pandemics would strengthen and empower the findings of the current research. Finally, future research on register analysis could exploit Antconic Software in creating a corpus of WHO register of pandemics. 


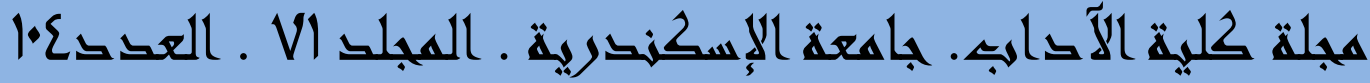

\section{References}

Anthony, L. (2019). AntConc Build 3.5.8. (Computer Software).

Retrieved from https://www.softpedia.com/get/Science-

$\mathrm{CAD} /$ AntConc.shtml

A. Carusi and A. de Waard, "Changing modes of scientific discourse analysis, changing perceptions of science," 20095 th IEEE International Conference on E-Science Workshops. Retrieved fromhttps://www.researchgate.net/publication/251918896_Changing _modes_of_scientific_discourse_analysis_changing_perceptions_of_science

Biber, D. et al. (2012). Longman Grammar of Spoken and Written.

English. Harlow Essex: Longman.

Biber, D. and Conrad, S. (2019). Register, Genre and Style.

Cambridge: Cambridge University Press.

Dorland, W. A. N. (2012). Dorland's Illustrated Medical Dictionary. Philadelphia, PA: Elsevier Saunders.

Freed, Alice. (2015). "Institutional Discourse." In The International Encyclopedia of Language \& Social Interaction, Karen Tracy, Cornelia Ilie, \& Todd Sandel, (eds.). Boston: John Wiley \&

Sons. Retrieved from https://www.researchgate.net/publication /273123803_Institutional_Discourse_In_The_International_ Encyclopedia_of_Language_Social_Interaction_Karen_Tracy_ Cornelia_Ilie_Todd_Sandel_eds_Boston_John_Wiley_Sons_ Pp_809-826_2015

Finegan and Biber (1994). Sociolinguistic perspectives on register. New York ; Oxford : Oxford University Press.

Gokhman, Kristina. (2019). Academic Discourse within the System of Institutional Discourses. Naukovy Visnyk of South Ukrainian National Pedagogical University named after K. D. Ushynsky: Linguistic Sciences. Retrieved from https://www.researchgate.net/publication/331243371_Academic Discourse_within_the_System_of_Institutional_Discourses

Gray, B. (2015). Linguistic Variation in Research Articles: When Discipline Tells only Part of the Story. Amsterdam: John Benjamins Publishing Company. 
Garrafa, V. (2014). "Solidarity and Cooperation" Henk A. M. J. ten Have; Bert Gordijn (eds) Handbook of Global Biothetics. Springer Science and Business Media Dordrecht (p. 169- 186).

Hernandez-Campoy, J. M. (2019). Sociolinguistic Styles. New Jersey: John Wiley \& Sons, Inc.

Holmes, J. (2013). An Introduction to Sociolinguistics. $4^{\text {th }}$ ed. London, New York: Routledge.

Jablonski, S. (2016). Dorland's Dictionary of Medical Acronyms \& Abbreviations. Philadelphia, PA: Elsevier.

Jasarevic, T., Ryan, M., Van Kerkhove, M., Ghebreyesus, T. (2020 Jan 29). "Novel Coronavirus Press. Conference at United Nations of Geneva".World Health Organization. [Accessed 2020 Mar 31]. Retrieved from https://www.who.int/docs/defaultsource/coronaviruse/transcripts/who-audio-script-ncovrresser-unog-29jan2020.pdf?sfvrsn=a7158807_4

Mayr, Andrea. (2008) Language and Power: An Introduction to Institutional Discourse. London: Bloomsbury Publishing Plc.

Neumann, S. (2014). Contrastive Register Variation: a Quantitative Approach to the Comparison of English and German. Berlin: De Gruyter Mouton.

Popova, Tatiana. (2015). Characteristics of Institutional Discourse. Historical and social-educational ideas. Retrieved from https://www.researchgate.net/publication/306371287 CHARACTERISTICS_OF_INSTITUTIONAL_DISCOURSE

PHEIC. (n.d.) TheFreeDictionary.com. (2020). Retrieved June 42020 from https://acronyms.thefreedictionary.com/PHEIC

Roberts, Celia. (2011). " Institutional discourse ". The Routledge Handbook of applied linguistics. Ed. James Simpson. London : Routledge.

Rusko, Tatjana. (2014). Lexical Features of Scientific Discourse. Retrieved from https://www.researchgate.net/publication/274550840 Lexical_Features_of_Scientific_Discourse 


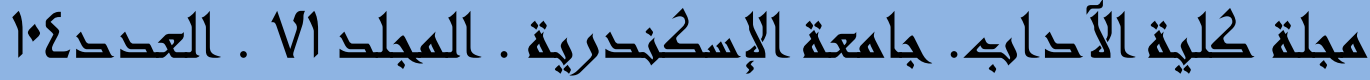

Sitrep. (n.d.) Segen's Medical Dictionary. (2011). Retrieved June from https://medical-dictionary.thefreedictionary.com/sitrep

Schubert, C. and Sanchez-Stockhammer, C. (2016). Variational text linguistics: revisiting register in English. Berlin/Boston: De Gruyter.

Teich, E. (2012). Cross-linguistic Variation in System and Text. Hawthorne: De Gruyter Mouton.

Thornborrow, Joanna . (2016). Power Talk: language and interaction in institutional discourse. Routledge.

Tenbrink, T. (2020). Cognitive Discourse Analysis: an Introduction. Cambridge: Cambridge University Press

Vold, E. T. (2012). "The choice and use of epistemic modality markers in linguistic and Medical Research articles". Academic Discourse Across Disciplines. Marina Band, and Ken Hyland Bem, Suisse Peter Lang.

Wälchli , B. and Szmrecsanyi, B. (2014). "The text-feature-aggregation pipeline in variation studies". Aggregating Dialectology, Typology, and Register Analysis Linguistic Variation in Text and Speech. Ed. Benedikt Szmrecsanyi and Bernhard Wälchli. Walter de Gruyter GmbH, Berlin/Boston.

Wardhaugh R. and Fuller, J.M. (2015). An Introduction to

Sociolinguistics. Chichester, West Sussex, UK ; Malden, MA : Wiley Blackwell.

Yesterday. (n.d.). In Merriam-Webster's online dictionary ( $11^{\text {th }}$ ed.).Retrieved from https://www.merriam-webster. com/ dictionary/yesterday 


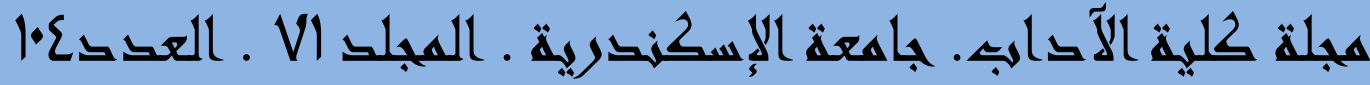

تحليل استطرادي للخطاب المؤسسي الموجه للجمهور: دراسة حاله لوباء Covid-19

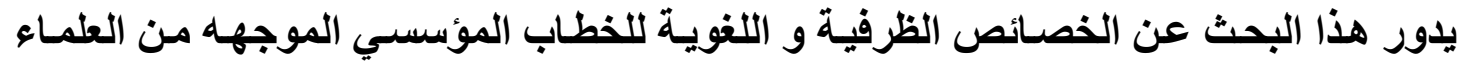

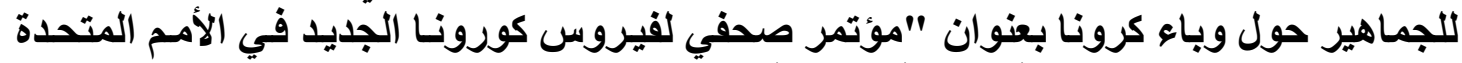
بجنيف" والذي ترعاه منظمة الصحة العالمية.

ويهذف هذا البحث الى معرفة الخصائص الظرفية و مدىى تأثيرهـا على الاستخدامات اللغويـة

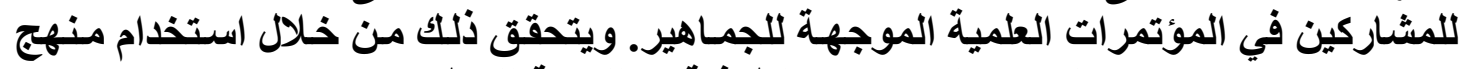

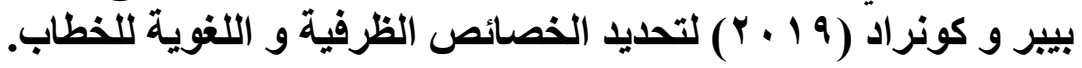

يتميز الخطاب موضوع الاراسة بقار من التفاعل بين المشاركين من علمـاء وصحفيين ويبدو

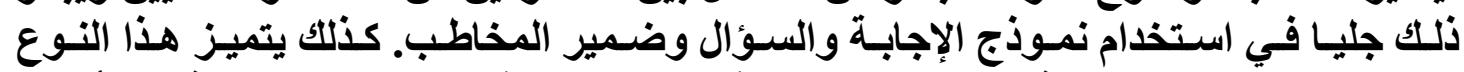

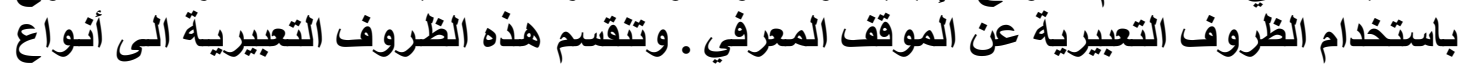

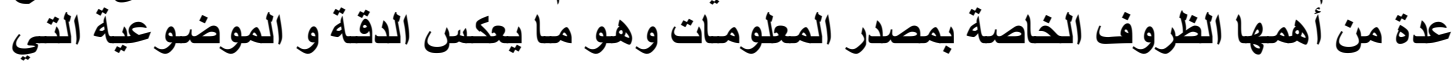

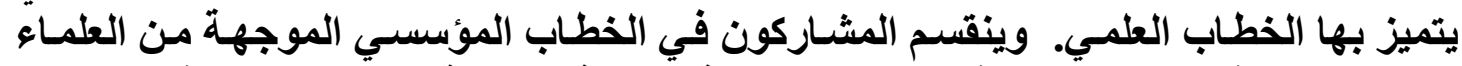

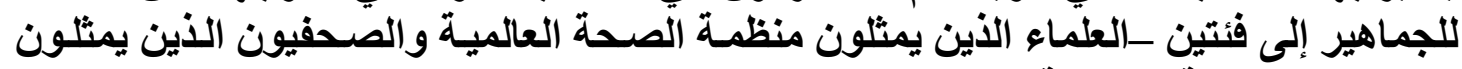
الوكالات الاخبارية المختلفة.

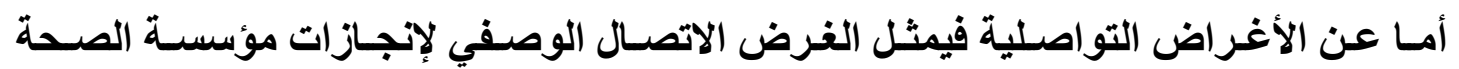

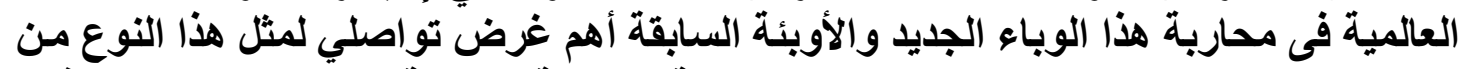

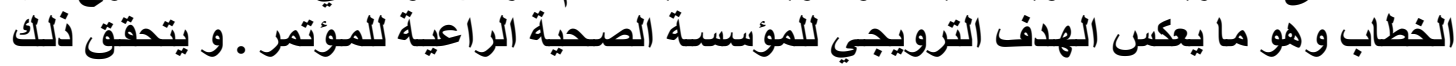

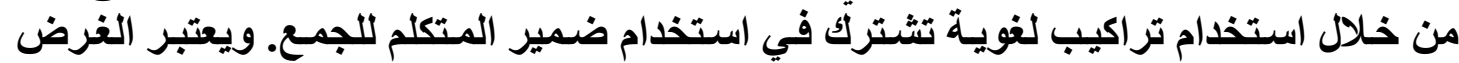

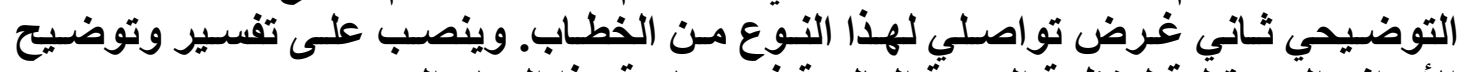

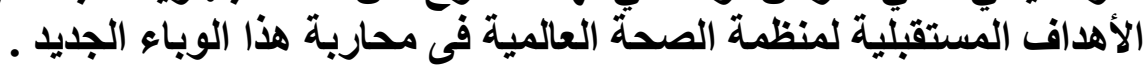

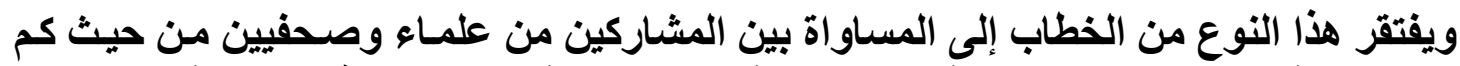

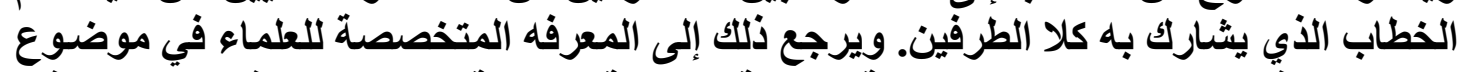

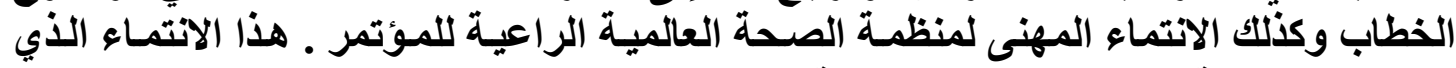
يضفى المصداقية على الاسهامات الكلامية للعلماء . 